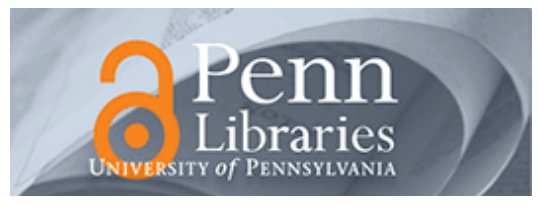

University of Pennsylvania ScholarlyCommons

Finance Papers

Wharton Faculty Research

2009

\title{
The Euro and Corporate Valuations
}

Arturo Bris

Yrjo Koskinen

University of Pennsylvania

Mattias Nilsson

Follow this and additional works at: https://repository.upenn.edu/fnce_papers

Part of the Finance Commons, and the Finance and Financial Management Commons

\section{Recommended Citation}

Bris, A., Koskinen, Y., \& Nilsson, M. (2009). The Euro and Corporate Valuations. Review of Financial Studies, 22 (8), 3171-3209. http://dx.doi.org/10.1093/rfs/hhn101

At the time of publication, author Yrjo Koskinen was affiliated with Boston University School of Management and CEPR. Currently, he is a faculty member at the Wharton School at the University of Pennsylvania.

This paper is posted at ScholarlyCommons. https://repository.upenn.edu/fnce_papers/241

For more information, please contact repository@pobox.upenn.edu. 


\title{
The Euro and Corporate Valuations
}

\begin{abstract}
In this paper, we study the changes in corporate valuations induced by the adoption of the euro as the common currency in Europe. We use corporate-level data from seventeen European countries, of which eleven adopted the euro. We show that the introduction of the euro has increased Tobin's $Q$-ratios by $17.1 \%$ in the \{euro-area\} countries that previously had weak currencies. Part of the increase in corporate valuations is explained by the decrease in interest rates and by the decrease in the cost of equity. The increases in Tobin's $Q$ are larger for firms that would be harmed by currency devaluations.

\section{Disciplines}

Finance | Finance and Financial Management

\section{Comments}

At the time of publication, author Yrjo Koskinen was affiliated with Boston University School of Management and CEPR. Currently, he is a faculty member at the Wharton School at the University of Pennsylvania.
\end{abstract}




\title{
The Euro and Corporate Valuations*
}

\author{
Arturo Bris ${ }^{\dagger} \quad$ Yrjö Koskinen ${ }^{\ddagger} \quad$ Mattias Nilsson ${ }^{\S}$
}

November 2007 


\begin{abstract}
In this paper we study the changes in corporate valuations induced by the adoption of the euro as the common currency in Europe. We use corporate-level data from 17 European countries of which 11 adopted the euro. We show that the introduction of the euro has increased Tobin's Q-ratios by $17.1 \%$ in the euro-area countries that previously had weak currencies. Part of the increase in corporate valuations is explained by the decrease in interest rates and by the decrease in the cost of equity. The increases in Tobin's $Q$ are larger for firms that would be harmed by currency devaluations.

KEYWORDS: Economic and Monetary Union (EMU), the euro, valuation, cost of capital, currency risk, currency union.

JEL classification: F33, F36, G32
\end{abstract}


Economic and Monetary Union (EMU) and the resulting introduction of a common currency for Europe on January 1, 1999, is arguably the most important institutional change in international financial markets during the past quarter century. Despite the historic significance of the new currency, the euro has aroused a considerable amount of controversy throughout its short history. The euro-skeptics have blamed the common currency for the disappointing macroeconomic performance in the euro countries. ${ }^{1}$ Even within the euro countries the euro has been criticized. ${ }^{2}$ The euro has existed for a short time, and a thorough empirical analysis of its economic effects is very hard at this point. However, assessing the economic impact of the euro is very important, since some new members of the European Union are considering joining the EMU, while others -the UK in particular- have long delayed or refused to join arguing that the costs outweigh the benefits. This paper aims to address the economic impact of the euro by looking at changes in the valuations of European corporations around the introduction of the common currency. Corporate valuations are a very appropriate way of assessing the impact of the euro keeping in mind the short history of the new currency, since stock prices are forward looking and hence react fast to structural changes that may have long-term consequences.

We use corporate-level data from eleven countries that adopted the euro, ${ }^{3}$ the three EU countries (Denmark, Sweden, and the UK) that did not, as well as Norway and Switzerland. Using data as of December 31 each year, we study how the introduction of the euro has affected firms' Tobin's Q in panel regressions that span from 1994 to 2004 . We use 1998 as the benchmark year for adoption of the euro for two reasons: First, on May 2, 1998, the European Council decided which countries were allowed to enter the final phase of EMU. Second, the forward rates in all euro countries converged around the middle of 1998, implying that using the 1997 observation would be premature and using the 1999 actual introduction of the common currency would be too late.

There are two main channels through which the euro may increase the value of corporations. As the value of a firm equals the sum of expected future cashflows discounted at the cost of capital, the euro may have an effect on firm value by increasing expected cashflows, or by decreasing the cost of capital. The euro may increase firms' expected cashflows by reducing transaction costs and increasing trade in goods and services within the currency 
union - the benefits of a shared currency already identified by Mundell (1961) in his seminal paper. The euro could reduce cost of capital through two channels: First, the euro could reduce the risk-free interest rate, especially for those countries that had high real risk-free rates because of credibility problems in monetary policy. Second, the euro could reduce the market risk premium. Perhaps the most obvious way the euro could reduce market risk premium is through eliminating intra-European currency risks, especially risks stemming from unilateral currency devaluations. The euro may have also decreased market risk premium by facilitating risk sharing among investors in EMU-countries.

We provide evidence of firm value increases that are consistent with the two channels. First, we show that in the period 1998-2004, Tobin's Q for firms in the euro countries have increased by 9.0 percent compared to firms in non-euro countries, after controlling for firm, country, and time specific effects. When we control for changes in monetary policy and macroeconomic expectations by including the short-term rate and the term-spread as explanatory variables, the increase in Tobin's Q is 7.8 percent. This implies that only part of the overall increase in corporate valuations spurred by the euro is due to changes in interest rates.

We find that the effect of the euro on corporate valuations is more significant for the group of countries - Finland, Italy, Ireland, Portugal, and Spain - that devalued their currencies during the $\mathrm{ERM}^{4}$-crisis of 1992-93. We label these countries as the "weak-euro countries." For this group, the increase in Tobin's Q is 12.8 percent after controlling for changes in interest rates. Since the weak-euro countries are the ones for which the elimination of currency risks was more valuable ex-ante, this evidence supports the hypothesis that the euro has led to a reduction in currency risk and hence in the market risk premium. This is confirmed by the finding that, even within firms in weak-euro countries, the increase in Tobin's Q is much larger among those firms whose stock returns were negatively correlated with depreciations of the domestic currency. For those firms the increase in Q after 1998 is an additional 6.4 percent.

Some of our results are also consistent with an increase in expected cashflows. We show that Tobin's Q for firms in strong-euro countries increases 6.1 percent after 1998, irrespective of the firm's currency exposure and after controlling for changes in interest rates. This finding 
is consistent with the reduction of market risk premium resulting from better risk sharing opportunities. However, we also compute a proxy for the cost of equity capital, and show that although it is negatively related to Tobin's Q, reductions in the cost of equity can only explain 0.5 percent of the increase in the Tobin's Q in strong-euro firms, and 1.3 percent of the increase in Tobin's Q in weak-euro firms. Thus we conclude that the euro has also affected expected cashflows positively.

There are some alternative explanations for our findings. In principle, we document increases in Tobin's Q after 1998. But this period is also a period of macroeconomic convergence of euro countries following the Maastricht Treaty. Therefore, it can be possible that firm valuations have increased as a result of this process of budget deficits, government debt reductions and price stability. However, we document that, even after controlling for changes in these variables, the increase in Tobin's Q is a significant 15.3 percent for the weak-euro countries.

In sum - the euro has increased the value of the firms that we expect ex ante to benefit the most from it: firms in countries with weak currencies, and firms that were harmed by currency depreciations. This suggests that the benefits of the euro come, to a large extent, from the elimination of currency risks, especially the risk of unilateral devaluations. In Section 1, we discuss the relationship between currency risks, devaluations, and firm value, and argue that the common currency can increase valuations through a reduction in the firm's cost of equity.

The paper is organized as follows: Section 1 describes the theoretical relationship between the euro and corporate valuations. In Section 2, we describe the data, and in Section 3, we study the valuation effects of the common currency. In Section 4, we further analyze the causes for valuation changes, and in Section 5, we study the impact of cost of equity changes. Section 6 is devoted to additional robustness checks, and Section 7 concludes.

\section{The Euro and Firm Valuations}

The euro can affect corporate valuations through two channels: It can have an impact either on the firms' cost of capital, or on expected cash flows. First, the euro can affect a 
firm's cost of capital in several ways:

- A main component of the cost of capital is the risk-free interest rate. The real risk-free rates may have changed in Europe because since 1999, there is a common monetary policy for the euro countries. The euro should have lowered real interest rates for those countries that previously faced credibility problems in maintaining price stability. Alesina and Barro (2002) argue that currency unions like the euro can be a good commitment mechanism to monetary stability, and that they are especially beneficial for countries that have suffered from high inflation rates.

- Another component in the cost of capital is the risk premium, including a risk premium for currency risks. The adoption of the euro as a common currency of course means that the nominal intra-European currency risks between the euro countries have been eliminated. By using currency hedging, companies can eliminate some or all of their foreign currency exposure. However, if firms do not fully hedge, ${ }^{5}$ currency risk is priced in financial markets, as implied by the international capital asset pricing model (see, for instance, Adler and Dumas, 1983; Dumas and Solnik, 1995; De Santis and Gerard, 1998). Also, there are instances when firms are not able to hedge even if they would like to -for example when impending currency devaluation dries the liquidity out of the markets. In those cases, the elimination of currency risks should lead to a lower cost of capital ${ }^{6}$.

- Financial market integration could have reduced the overall cost of capital through better risk sharing opportunities (Bekaert and Harvey, 1995; Stulz, 1999). In particular, the euro may have increased financial integration in Europe and reduced the home equity bias by eliminating investment restrictions that some institutional investors had prior to the adoption of the euro ${ }^{7}$. European pension funds typically have currency matching rules, for example that they cannot allocate more than 20 percent of their funds to assets denominated in a foreign currency. Before the common currency was adopted, all securities denominated in another European currency were subject to this restriction. Of course this restriction is now void for investments within the euro-area. There is some evidence that investors in the euro countries have started to diversify 
their holdings more internationally. Hardouvelis, Malliaropoulos, and Priestley (2006) report that foreign equity holdings as a proportion of total equity holdings have increased from 29 percent in 1992 to 50 percent in 1999 for pension funds in the euro countries, whereas for pension funds from other countries, the share of foreign equity has remained almost the same.

- The euro may also have decreased the cost of capital through increased competition in European financial markets. Rajan and Zingales (2003) show that the euro has had a significant positive impact on the amount of corporate bond issuance, which almost tripled after the introduction of the common currency. Thus bond markets have become a viable alternative to borrowing from banks.

In sum, corporations can be more valuable after the introduction of the euro because the cost of capital has decreased due to lower real interest rates, due to the elimination of intra-European currency risks, due to better risk sharing in European financial markets, or due to increased competition among providers of finance.

The second channel through which the euro could have affected corporate valuations, is the increase in firms' expected cash flows. Higher cash flows can be the result of an increase in trade in the euro area. Rose (2000) and Glick and Rose (2002) argue that common currencies have an enormous impact on bilateral trade flows between countries that share the same currency. Rose and van Wincoop (2001) estimate that the euro would increase intra-European trade by 50 percent. More recent papers demonstrate positive trade effects, but they are not as large as the earlier estimates. For example, Bun and Klaassen (2007) find that the euro has increased trade by 3 percent and Baldwin (2006) estimates that the increase in trade is 9 percent within the euro-countries.

\section{Data Description}

\section{$2.1 \quad$ Sources}

The sample of firms used in this study is gathered from Worldscope and covers the period 1994-2004. The sample includes firms from all the countries that adopted the euro, with the 
exception of Greece. Greece is excluded because it is hard to classify it as either a euro or a non-euro country in the time period from the introduction of the euro in January 1999 until it actually adopted the common currency in January 2001. ${ }^{8}$ Thus our sample includes firms from the following eleven countries that have adopted the euro: Austria, Belgium, Finland, France, Germany, Ireland, Italy, Luxemburg, the Netherlands, Portugal, and Spain. The sample also include firms from the three remaining EU, non-euro countries (Denmark, ${ }^{9}$ Sweden, and the UK) as well as firms from Norway and Switzerland. We consider these five non-euro countries to constitute appropriate benchmark countries for an analysis of the impact of the euro on firm value.

For our 16 sample countries, we require that firms have data available in Worldscope for at least one year before and one year after the introduction of the euro, as defined below. Because we do not require that the firms exist for the whole sample period of 1994-2004, we end up with an unbalanced panel of firms. ${ }^{10}$ We exclude firm-years observations with (i) zero sales, (ii) negative earnings (EBITDA) in excess of the book value of assets, or (iii) negative book values of equity. These exclusions are done to ensure that speculative or severely distressed firms do not have an undue influence on our results. We also winsorize the variables in the sample at the 1st and 99th percentiles to take into account potential implausible figures and transcription errors in Worldscope. Our final sample consists of 4,242 firms (36,246 firm-year observations): 2, 017 firms (17,500 firm-year observations) from the euro countries and 2,225 firms (18,746 firm-year observations) from the non-euro countries. France contributes the most firms to the euro sample with 598 firms (4,936 firmyear observations), whereas the UK dominates the non-euro sample with 1, 513 firms (12, 672 firm-year observations). Our results are robust even when we exclude both France and the UK from the sample. See Table 1 for a classification of the sample firms by country of nationality.

\section{[INSERT TABLE 1]}




\subsection{Country Classifications}

First we classify firms into two groups, depending on whether they are euro countries or not. Next we further group firms within the euro group, depending on the stability of their home country currencies relative to the German mark ${ }^{11}$ prior to the introduction of the common currency. We classify weak-euro countries as those that significantly devalued their currencies with respect to the German mark during the currency crisis of 1992-93. These countries are Finland, Ireland, Italy, Portugal, and Spain. ${ }^{12}$ Six other euro countries

- Germany, France, Netherlands, Austria, Belgium, and Luxembourg ${ }^{13}$ - did not experience significant currency depreciations during the currency crisis in early 1990s, hence the label strong-euro countries. ${ }^{14}$ The classification into weak- and strong-euro countries is important, because the previous monetary arrangement in Europe did not manage to provide a credible commitment against devaluations for the weak-euro countries and hence the introduction of a common currency could be especially significant for these countries. Notice that the labels of weak- and strong-euro countries only apply to the weakness and strength of the currencies prior to the EMU, and not to the overall economic performance of the respective countries.

Alesina and Barro (2002) argue that a currency union like the EMU provide a more credible commitment mechanism than unilateral pegs or currency boards. It is easy to change the external value of a currency, when the currency is unilaterally pegged to another. ${ }^{15}$ It is arguably very hard for any single country to leave the EMU, because it has not designed an explicit break-up process. Hence, some authors have argued that the EMU is irreversible (Scott, 1998).

\subsection{Firm Characteristics}

Appendix $\mathrm{C}$ shows the detailed definition of all the variables in our study. Our measure of firm value is Tobin's $\mathrm{Q}^{16}$, which is calculated in the paper as the book value of total assets minus the book value of the common equity, plus the market value of the common equity, divided by the book value of total assets. ${ }^{17}$ Table 1 reports descriptive statistics for Tobin's $\mathrm{Q}$ as well as for other firm characteristics that we use in our analysis. The market value of equity is recorded as of December 31 each year. For all other firm characteristics, the data 
is from the end of each firm's fiscal year. ${ }^{18}$ Table 1 shows that average and median Qs are significantly larger in the non-euro countries when calculated over the entire sample period. The table also shows that EMU firms, relative to non-euro firms, are: (i) larger, (ii) more leveraged, and (iii) have less fixed assets. These average differences in firm characteristics between the EMU and non-euro countries are taken into account in our analysis through the use of fixed firm effects (see below).

One issue that we consider in the analysis is that increases in Tobin's Q must be driven by increases in market values, but also by reduction in the book value of assets. If the firms that adopt the euro changed their investment policies (see Bris, Koskinen, and Nilsson, 2006), we will observe a change in Tobin's $\mathrm{Q}$ which is unrelated to the market valuation. To address this initial concern, we control in our cross-sectional regressions for measures of investment (the ratio of capital expenditures to total assets, as well as the ratio of net fixed assets to total assets). Additionally, we provide further evidence on valuation effects by analyzing stock prices around the introduction of the euro in Section 6.6.2. Finally, we also report results based on a measure of Q adjusted by the worldwide yearly median in the industry, to control for the possibility that measurement errors are not only country-specific but also industry-specific.

A final issue of concern that can cause differences in Tobin's $Q$ is the difference in consolidation rules among countries. As many continental European companies own stakes in other firms, this can lead to problems in the computation of the $\mathrm{Q}$ ratio. La Porta, Lopez-de-Silanes, Shleifer, and Vishny (2002) perform a thorough estimation of Q with and without taking into account consolidations, and find that the correlation between the two measures is 0.82 . Moreover they confirm that their results remain unchanged after adjusting Tobin's Q. We take this problem into account by estimating our cross-sectional regressions with firm-fixed effects. Therefore, unless there is any systematic change in these stakes after the introduction of the euro, accounting consolidation does not pose any problem to our analysis. We get data from the Securities Data Corporation on stake purchases by firms in the 16 countries in our sample which are larger than 50 percent. There is an increasing number of purchases in euro-countries (the number triples in the post-1998 period relative to the pre-1998 period) in comparison to the non-euro countries (the number of purchases 
doubles). While the increase in market values is sizeable, the increase in book values is lower than in non-euro countries, which suggests that acquisitions by euro firms have become more frequent, but smaller. We have run panel regressions to test for any pattern, but the effect of the introduction of the euro is not significant.

\section{The Euro and Firm Value}

\subsection{Choice of Post-Euro Time Period}

The aim of this study is to analyze whether the introduction of the euro has led to a structural change in corporate valuations for the participating countries. Thus, we need to identify the point in time when the structural change occurs. The euro was officially introduced on January 1, 1999. However, it was on May 2, 1998, that the European Council decided which countries were allowed to enter the final phase of the EMU. Thus, since our data is as of December 31 each year, choosing (the end of) 1998 as the first year of the euro seems reasonable. One objection to this choice is that forward looking markets are likely to have already taken into account the effects of the introduction of the euro at the end of 1997, or even earlier. ${ }^{19}$

Hardouvelis et al. (2006) use the forward interest rate differential with Germany as a measure of convergence to the EMU and show that financial integration among European markets was positively related to that measure. We also calculate forward rate differentials as in Hardouvelis et al. (2006) to get an indication of the likelihood of countries joining the EMU. The calculations are outlined in Appendix A. Favero, Giavazzi, Iacone, and Tabellini (1997) criticize deriving the probabilities for joining the EMU from simple forward rate spread calculations. They show that probabilities based on average forward rates overes-

timate the true probabilities. Hence we do not try to interpret the spreads in terms of probabilities. However, to the extent that actual forward rate spreads are different from zero, their magnitude reflects that the markets assign some positive probability to a country not joining the EMU.

[INSERT FIGURE 1] 
Figure 1 shows the average forward rate spread for the non-euro countries, as well as for the strong-euro and weak-euro countries. While spreads outside the EMU do not converge to zero, it is clear from the figure that, following a sharp decline in the years 1996 and 1997, forward rate spreads converge to zero in mid-1998 in the euro countries. This is especially true for the weak-euro countries.

In order to avoid drawing inferences from the forward rate spread levels, we estimate the incremental changes on forward rate spreads by regressing the absolute value of the monthly forward spreads ${ }^{20}$ on country and time dummy variables that are constructed in the following way: For each year $T$, we construct a dummy variable that takes value one whenever $t \geq T$, and zero otherwise, where $t$ is the date when we observe the corresponding forward spread. The coefficients for such time dummies measure the incremental effect on spreads for each corresponding year. The results in Table 2 show that there are significant reductions in spreads for all countries in years 1996 and 1997. However, the regression results show a final, permanent convergence in spreads in 1998, both in the weak- and strong-euro countries. Indeed, the reduction in the absolute spread is 2.3 percent in the weak-euro countries, and 0.4 percent in the strong-euro countries. The average spreads as of December 1998 in the non-euro, weak-euro, and strong-euro countries are, respectively, 5.37 percent, 0.27 percent, and 0.00 percent, and they do not change afterwards for the EMU-countries. ${ }^{21}$ We can thus conclude that it is not until 1998 that the uncertainty regarding which countries would adopt the euro disappears. Based on these results, we consider the end of 1998 to be a reasonable and conservative choice for the start of the post-euro time period. But because the above results show that markets in 1997 had already anticipated that the strong-euro countries would adopt the euro, we will also test the robustness of our results to alternative definitions of the post-euro time period.

\section{[INSERT TABLE 2]}

\subsection{Univariate Analysis}

Table 3 reports the average Tobin's Q of the sample firms before and after 1998. Besides reporting averages based on absolute Tobin's Q values, we also report averages based on 
industry-adjusted Qs. The industry-adjusted Tobin's Q is computed as the firm's Q minus the median $\mathrm{Q}$ of the firms in the corresponding 2-digit SIC group, computed across all countries covered by Worldscope. As can be seen in Table 3, Tobin's Q is larger in the noneuro countries than in the euro countries before 1998 (1.74 vs. 1.51, significant difference at the 1 percent level), and it is larger in strong-euro countries than in weak-euro countries (1.59 vs. 1.29 , significant difference at the 1 percent level). Although the magnitude of the difference shrinks, this ranking remains after the introduction of the common currency, and it does not depend on whether we measure $Q$ in absolute values, or adjusted by industry.

It is interesting that, except for the weak-euro countries, Tobin's Q falls significantly after 1998, and especially in non-euro countries (a drop in Q of 0.28). However, the industryadjusted Q increases in the euro area in 1998-2004 with respect to the previous years: The increase is 0.07, significant at the one percent level. But if falls in non-euro firms (0.29 vs. 0.41 before 1998).

\section{[INSERT TABLE 3]}

\subsection{Regression Analysis: Method and Main Results}

\subsubsection{Method}

To analyze the effects of the introduction of the euro we estimate a fixed-effects panel regression model for the 1994-2004 time period with the logarithm of Tobin's Q as the dependent variable. As a robustness measure, we also use the industry-adjusted Tobin's Q as our dependent variable. The impact of the euro is measured using a dummy variable, "EMU country x post-euro time period," which takes the value one for firms in the euro countries for years 1998-2004, and zero otherwise. Alternatively, we use two dummy variables indicating firms in the strong- and weak-euro countries, respectively, in the post-euro time period. More formally, we estimate the following model by OLS:

$$
\log Q_{i c t}=Y_{t}+F_{i}+\beta X_{i c t}+\gamma Z_{c t}+\delta E U R O_{c t}+\varepsilon_{i c t},
$$

where $Q_{i c t}$ is Tobin's $\mathrm{Q}$ for firm $i$ in country $c$ at time $t, Y_{t}$ is the fixed time effect for year $t, F_{i}$ is the fixed firm effect for firm i, $X_{i c t}$ represent firm characteristics, $Z_{c t}$ represents 
country characteristics, and $E U R O_{c t}$ is the dummy variable(s) indicating whether the euro was adopted or not by country $c$ at time $t$. The estimated effect of the euro is captured by $\widehat{\delta}$.

The fixed year effects capture common time trends across both euro- and non-euro-firms. By using firm-specific fixed effects, we simultaneously control for both constant country factors (e.g., taxation, accounting rules, legal environment) and for constant firm factors (e.g., industry effects ${ }^{22}$ ). The firm characteristics used as controls $\left(X_{i c t}\right)$ are: size, measured as the log of the firm's sales (in euros); profitability, measured as the ratio of earnings before interest, taxes, depreciation, and amortization (EBITDA) to total assets; leverage, measured as the book value of non-equity liabilities divided by total assets; the ratio of fixed tangible assets to total assets; the ratio of capital expenditures to total assets; and the ratio of $\mathrm{R} \& \mathrm{D}$ expenses to total assets. Firm size is included because smaller firms tend to have greater growth opportunities. The tangibility of assets is typically negatively related to the firm's investment opportunities, whereas capital expenditures and R\&D expenses are positively related. Leverage has been found to have a negative effect on Tobin's Q (McConnell and Servaes, 1990). Profitability directly affects a firm's value.

As country controls $\left(Z_{c t}\right)$, we use real GDP growth rate and the log of GDP per capita to account for cross-country differences in the business cycle and wealth. Furthermore, the euro first depreciated and then appreciated dramatically with respect to the US dollar during our time period. Therefore, we also include the yearly change in the domestic currency/USD exchange rate as a control to make sure that our results are not caused by a significant depreciation or appreciation of the euro or its legacy currencies with respect to the dollar. We gather data on the exchange rate of domestic currency/USD during the sample period from Datastream. After 1998, the exchange rate for each EMU country is implicitly obtained from the euro/dollar exchange rate. We then calculate the change in the exchange rate for each country and year in the sample.

We further want to find out if the possible changes in $Q$ are due to changes in the level of interest rates induced by the new monetary policy environment. In unreported regressions we find that, relative to non-euro countries, short-term interest rates in weak-euro countries fell by 2.4 percent after 1998, while there was not significant decline in short rates in the 
strong-euro countries. As we described earlier, lower interest rates imply a lower cost of capital and therefore a higher firm value. Thus, our results could simply reflect the impact of the monetary union on participating countries' risk-free interest rates. Therefore, we control for the level of short-term interest rates by including the 6-month risk free rate in our Q regressions for each country. ${ }^{23}$ In addition, monetary policy is also an important determinant of the term structure spread (see, for instance, Estrella and Mishkin, 1997). Hence we include the term-spread as an explanatory variable as well (10-year government bond rate minus the 6 -month t-bill rate).

Equation (1) is a typical example of a differences-in-differences (DD) estimation, where we try to identify a causal relationship between a treatment (the introduction of the euro) and an endogenous variable for a large number of firms from both affected and unaffected countries. To deal with the fact that the standard errors in a DD estimation are biased due to serial correlation, we estimate robust standard errors that are adjusted for clustering of observations by country. This is one of the methods for dealing with serial correlation in DD estimation suggested by Bertrand, Duflo, and Mullainathan (2004). Another method suggested by Bertrand et al. for dealing with this problem is a time-series, simple aggregation of the data. The method consists of ignoring all time-series effects by averaging the data before and after the regime change and then run the DD estimation on the resulting twoperiod panel data set. We use also this method as a robustness test. To this end, we

first calculate pre- and post-euro firm averages for all the variables in the dataset, thereby obtaining two observations per firm. We then run the main Q regressions on this two-period panel where the year fixed effects are replaced by one dummy variable indicating the posteuro time period.

\subsubsection{Main Estimation Results}

Panel A of Table 4 presents the results of DD-estimation using the full panel of data with standard errors adjusted for clustering at the country level. Because the endogenous variable in our regression is the $\log$ of $\mathrm{Q}$, the interpretation of the coefficients is straightforward and represents the percentage change in $\mathrm{Q}$ induced by either being a strong euro country, being a weak euro country, or in general adopting the euro in 1998. We also estimate the regressions 
using industry-adjusted $\mathrm{Q}$ as our endogenous variable, and all the results are qualitatively very similar.

\section{[Insert TABLE 4]}

Focusing on model (1), our first important result is that firm value in the euro countries has increased by 9 percent compared to non-euro countries from 1998 onwards. The coefficient is significant at the 5 percent level. The magnitude of the coefficient is important if we take into account that Tobin's Q decreases 7 percent on average in 1998-2004 with respect to 1994-1997 for euro-countries (Table 3). This implies that, ceteris paribus, EMU-firms grew in value not only compared to non-euro firms, but also relative to their own pre-euro values.

In model (2) of Table 4, we distinguish between strong- and weak-euro countries. Our results show, in line with Dumas and Solnik (1995), and Bodart and Reding (1999), that firms in countries with weaker currencies benefited more from the introduction of the euro. Firms in Finland, Italy, Ireland, Portugal, and Spain enjoy a 17.1 percent increase in Q relative to non-euro countries starting from 1998. Firms in strong-euro countries experience increases in valuation of 5.7 percent on average (the p-value for the difference of these two coefficients is below 0.001). These results are consistent with Alesina and Barro (2002), since our weak countries are precisely the countries that had more credibility problems in their monetary policies manifested by periodic currency depreciations.

Models (3) and (4) use the industry-adjusted Tobin's Q as the dependent variable. Results remain very strong. Overall, the euro-dummy coefficient is $0.137,{ }^{24}$ which is significant at the 5 percent level. The weak-euro-dummy is 0.251 , and the strong-euro-dummy is 0.091 (significant at the 1 and 5 percent levels, respectively).

We find our controls to have the expected signs in models (1) - (4). As a measure of firm-level growth opportunities, size is negatively related to value. More profitable firms are more valuable (significant coefficients in all estimations at the 1 percent level). Firm value decreases with leverage (significant at the 1 percent level). The ratio of tangible assets to total assets displays negative and significant coefficients. Firms with more growth opportunities (higher CAPEX) are worth more, although we do not find a significant effect on R\&D expenses. Perhaps somewhat surprisingly, increases in concurrent domestic economic growth 
have a positive impact on firm value (as expected), but the coefficient is only significant in some specifications. Finally, there is no evidence that the coefficient on the relative change in the domestic currency with respect to the US dollar is different from zero across the different model specifications.

\section{What Could Cause Increases in Valuations?}

\subsection{Changes in Interest Rates and Growth Expectations}

In this section we start exploring the potential reasons why firms in the euro area experience such high valuation increases. The first obvious candidate is the change in the risk-free interest rates, as discussed in Section 3.3. To test for this we include the short-term nominal interest rate for each country and year in models (5) to (8) in Table 4.

We also control for the term spread (the difference between the ten-year bond yield and the six-month rate), as a proxy for expected future GDP growth. Estrella and Hardouvelis (1991) and Jorion and Mishkin (1991), for instance, show that the term spread predicts future real economic activity. An increase in the spread is a measure of greater economic prospects, and indeed in unreported regressions we also find that the term spread has increased overall by 0.6 percent in euro countries, irrespective of whether they have weak or strong currencies. ${ }^{25}$

In model (5) of Table 4 we show that the reduction in short-term rates is significantly associated to increases in Tobin's Q. A one-standard deviation reduction in interest rates (3.88 percent) is associated with an increase in firm Tobin's Q of 10.86 percent. Because short rates fell by 2.4 percent in weak-euro countries, approximately one third of the 16 percent increase in value after 1998 in weak-euro countries can be attributed to reductions in short-term interest rates. Model (6) indeed confirms this result. (The coefficient "Weak-euro country x post-euro dummy" decreases to 0.115 from 0.167 , although the short-rate becomes marginally insignificant.) For the strong-euro countries, there is no change in the magnitude of the strong-euro dummy coefficient, since the short-rate does not fall (the coefficient, however, becomes marginally insignificant).

The term spread is not significant, which is evidence that future growth prospects do 
not lead to larger valuations, at least when we control for firm-specific factors that reflect future growth. Another reason could be that higher term-spread also predicts increases in future short-term interest rates (see for example, Fama, 1990, and Mishkin, 1990). Thus the interpretation for the increase in term-spread is ambiguous.

In summary, part of the effect of the euro on firm value can be attributed to interest rate reductions (about one third of the total effect). Reduction in interest rates are reductions in one of the main components of a firm's cost of capital. In the subsequent analyses, we always include the short-term nominal interest rate and the term premium as explanatory variables in our regressions.

When we use the industry-adjusted $\mathrm{Q}$ as a dependent variable, we find that valuations are not significantly higher in strong-euro countries after 1998. We argue that the entry of those countries - with the possible exception of Belgium - to the common currency area was well expected in 1998. Hence it is entirely possible that the positive effects had to a large extent already been incorporated into stock prices before 1998. Consistent with this reasoning Hardouvelis et al. (2006) find a significant decrease in cost of equity for the core-euro countries (except for Germany) prior to the introduction of the euro.

In Panel B of Table 4 we repeat the analysis in Panel A using the time-series aggregation method. The pooled dataset consists of 8, 484 firm-period observations (two observations per firm). Since the euro-dummy is significant at the 1 percent level both with and without the short-term interest rate and term-spread as explanatory variables, we confirm the results in panel A. As in Panel A, firms' Tobin's Q increases in weak-euro countries by 17 percent, and by 7.5 percent in strong-euro countries. Significance levels fall, but the magnitude of the coefficients reflects similar quantitative results to the ones described above.

Because our results using the aggregated sample do not differ significantly from the results in Panel A, we will in the remainder of the paper present results using the DD-methodology adjusted with an arbitrary variance-covariance matrix. Bertrand et al. (2004) prefer this method as well. 


\subsection{The Value of Macroeconomic Convergence}

Our results could be due to the introduction of the common currency, but also to macroeconomic developments caused by the oncoming monetary union. In fact, most of the countries that adopted the euro in 1999 went through a severe period of macroeconomic convergence. The Maastricht Treaty of February 1992 established the time frame and procedures for implementing the monetary union, including the criteria required for EU members to qualify for the third phase of the EMU. Our objective in this section is to determine the extent to which the valuation effects we have identified are driven by the euro itself, rather than by the convergence process that lowered interest rates, reduced budged deficits, government spending, and inflation. Some of the changes the euro countries implemented were actually dramatic: Belgium had a government budget deficit representing 8 percent of GDP in 1992. The deficit was 2 percent in 1998. Long-term interest rates went down in Spain from 14.7 percent in 1990 to 5.8 percent in 1997. As suggested by this example, most of the macroeconomic changes spurred by the convergence process happened before 1998, hence they should not be able to explain valuation changes after 1998. We now test their impact on our results.

We first construct measures of macroeconomic convergence. According to the Maastricht Treaty member states should fulfill the following criteria in order ti qualify for the third phase of the EMU: ${ }^{26}$

1. Price stability: The average rate of inflation should not exceed, by more than 1.5 percentage points, that of the three best performing member states in terms of price stability.

2. Government financial position: The deficit should not exceed 3 percent of GDP. In addition, the public debt should not exceed 60 percent of GDP, unless it is sufficiently diminishing and approaching 60 percent at a satisfactory pace.

3. Observance of the (normal) fluctuation margins provided for by the Exchange Rate Mechanism of the European Monetary System (EMS), without severe tensions for at least two years. 
4. Durability of convergence: The average of the long-term interest rate should not exceed by more than 2 percentage points that of the three best performing member states in terms of price stability.

We gather data on inflation, government deficit over GDP, long-term interest rates, and public debt over GDP from the Economist Intelligence Unit (EIU) database. We ignore convergence criterion (3) because it is already considered in our classification of countries into weak- and strong-euro countries. We calculate convergence requirements for each of the macroeconomic variables, and calculate the position of each country during each of the years 1994 to 2004 in two different ways. We calculate the Adjusted Convergence Variables as follows: If a country satisfies the corresponding convergence criterion, we assign a value of zero. Otherwise we compute the difference between the macroeconomic variable and the corresponding convergence requirement. The Unadjusted Convergence Variables are simply the raw values of the macroeconomic variables.

Note that we calculate the convergence variables for all the countries in our sample, including the non-euro countries. In fact Denmark fully satisfied the convergence requirements in 1997, but they opted out of the system. In 1998, all the non-euro countries in our sample already met the Maastricht criteria, except for the level of government debt in Sweden, which did not reach the Maastricht levels until 2001.

We also take into account changes in taxation. Corporate tax rates declined in Europe over the period 1995-2000 by an average of 9.5 percent. ${ }^{27}$ Interestingly, they fell more in euro countries (an average of 11.38 percent) than in non-euro countries (5.8 percent on average), with significant tax reductions in Ireland (where corporate tax rates fell from 36 percent in 1996 to 16 percent in 2000) and Italy (from 53.2 percent to 40.25). Thus, changes in corporate taxation could also be a potential explanation of our results. To control for this, we include the corporate tax rate for each country and year. ${ }^{28}$ Note that we do not include the short-term rate and the term-spread as explanatory variables because we use long-term nominal interest rates as an explanatory variable, as stipulated by the Maastricht treaty.

\section{[INSERT TABLE 5]}

In Table 5, we use both the adjusted and unadjusted convergence variables as explanatory 
variables. We show that the valuation effect we identify is caused by the introduction of the common currency itself, and not by the macroeconomic convergence process. We find that the euro yields positive valuation effects for firms from the weak-euro countries (15.2 percent significant at the 1 percent level), as well as the strong-euro countries (6.1 percent increase, significant at the 5 percent level). The coefficients for the convergence criteria variables are insignificant (except for the long-term rate in the first specification). One possible reason is that the results of the convergence process were well known before 1998 and already priced by the markets. Alternatively the convergence process suffered from credibility problems: markets may have believed that the convergence process could be reversed and that the results were only temporary.

Corporate tax rates have a significant effect on Tobin's Q, but with the opposite sign to what should be expected. One possible explanation is that reduction in corporate tax rates are typically accompanied by broadening of the tax base (see Desai, Dyck, and Zingales, 2007). Thus it is feasible that the amount of taxes paid has actually increased.

We also regress Tobin's Q on the values of the raw macroeconomic variables themselves, without adjusting for convergence. Once more, the effect of the euro is economically and statistically significant.

An alternative explanation for the increase in Tobin's Q is an increase in the frequency of cross-border mergers. Firms in the euro countries may have become very lucrative targets for other firms because by acquiring firms within the EMU, other firms coming from outside would gain better market access. If acquirers in cross-border mergers pay high premia and if firms in the euro countries are targets more often than other firms, firms in the euro countries will on average display valuation increases relative to other firms. In unreported regressions we examine this hypothesis. We find that the effect of cross-border acquisitions is insignificant, and the effect of the euro still remains the same.

\section{Additional Results}

In this section we provide evidence on which firms and countries are the most affected by the euro. We will show that Tobin's Q has increased the most for firms that are: (i) more 
exposed to exchange rate variability; (ii) smaller. Together with the results in Section 3, we are able to characterize the typical firm for which the effect of the euro has been economically significant.

\subsection{Exchange Rate Exposure and Firm Value}

Although all firms can benefit from the common currency, the euro should be of more benefit to those firms that were exposed to intra-European currency risks that existed before the introduction of the common currency. To study the effects of currency exposure, we sort companies within a country into three groups by using individual companies' stock market returns. In the first group we have companies whose stock returns significantly increase when the domestic currency depreciates with respect to the euro (positive-exposure companies). In the second group we place those companies whose stock returns significantly decrease (negative-exposure companies). The third group is for companies that did not have a significant currency exposure. We detail the computation of the exchange rate beta coefficients (ERBs) in Appendix B.

Positive ERBs imply that the firm's revenues are generated mostly in foreign markets, the firm's liabilities are mostly denominated in the domestic currency, and that the firm's currency exposure is not hedged by other means - derivatives or foreign financing. Conversely, a negative ERB is an indication that the firm's revenues originate mostly in the domestic market, the firm's liabilities are mostly denominated in a foreign currency, and that exposure to currency risk is not hedged. As a result, firms with positive ERBs have their assets positively exposed to currency depreciations. Similarly, firms with negative ERBs have their liabilities positively influenced by currency depreciations.

Table B1 in Appendix B shows the number of firms in each country with either positive or negative ERBs. We also report the median exchange rate beta among all firms in a given country. Only four countries in the EMU area have positive exposure: Germany, France, the Netherlands, and Portugal. Norway and Switzerland have positive exposure as well. On average, 14.41 percent of the firms in euro countries display a significant currency exposure at the 10 percent level in double-sided t-tests (or, equivalently, at the 5 percent level in one-sided t-tests), and 16.9 percent in the non-euro countries. 
In Table 6 we present the results of the fixed effects model with a further classification of euro-firms into significantly positive, significantly negative, and insignificant ERB firms.

\section{[INSERT TABLE 6]}

We first report that, irrespective of the sign and magnitude of the currency exposure, firm values in strong-euro countries have significantly increased 6.5 percent (significant at the 10 percent level after controlling for interest rate changes), while firms in weak-euro countries have increased 10.8 percent (significant at the 1 percent level). Firms with negative and significant ERB in weak-euro countries have enjoyed additional Tobin's Q increases of 6.4 percent. The difference between negative ERB firms in weak and strong euro countries is significant as well (p-value 0.010).

Therefore, a devaluation risk has commanded a high premium for those firms that were negatively exposed to currency depreciations in countries with weak currencies. This is consistent with the view that perhaps the major benefit from the euro has been the added exchange rate credibility against devaluations that the weak-euro countries have gained by adopting the common currency. However, the result that positive-ERB firms have also benefitted from the euro suggests that the elimination of devaluation risk is not the only factor at play.

\section{$5.2 \quad$ Large vs. Small Firms}

Some papers have argued that larger firms benefit more from integration, since large firms are more exposed to currency risks, and foreign investors prefer to invest in large firms (Dahlquist and Robertsson, 2001; Kang and Stulz, 1997). Bartram and Karolyi (2006) find that the decrease in systematic risk is bigger for multinational firms, indicating that cost of capital should have decreased more for larger firms. However, Allayannis, Lel, and Miller (2004) report that larger firms are much more likely to use derivatives to hedge their currency exposure, so that elimination of currency risks should not matter as much for larger firms. Therefore, it is an empirical question whether the benefits of the euro are different across firm size.

[INSERT TABLE 7] 
In Table 7 we classify firms into large and small, depending on their total sales, relative to the median sales of the firms in the sample in $1997 .{ }^{29}$ Among firms in strong-euro countries, we find that the effect of the euro is concentrated in small firms (increases in Tobin's Q of 5.9 percent, significant at the 5 percent level after controlling for changes in the short-rate and term spread). In weak-euro countries, although we find a larger effect for small firms (15.3 percent vs. 11.1 percent) the difference is not significant (p-value 0.312). Test of differences among coefficients show that the effect of the euro on small firms is significantly larger in weak-euro countries (p-value of the difference 0.077). Therefore, these results show that the effects of the euro are widespread among firms in weak-euro countries, and significant for small firms in strong-euro countries.

\subsection{Results by Country}

We provide results by country in Table 8 . Table 8 confirms that valuation results in general are stronger for countries we have labelled as the weak-euro countries. Among the strong-euro countries France and Belgium show the highest value increases (8.6 and 6.4 percent increases, respectively). These results fit well with these countries' experience during the ERM-crisis in 1992-93. Although France and Belgium did not devalue their currencies, they experienced several attacks against their currencies. Among the weak-euro countries valuation increases for Ireland are the smallest (the coefficient is not significant). Even though Ireland was forced to devalue its currency during the ERM-crisis, its currency subsequently recovered quite fast and as a result experienced the smallest devaluation among the weak-euro countries. ${ }^{30}$

\section{[INSERT TABLE 8]}

\section{Confirming Evidence}

In this section we provide more confirming evidence regarding our previous results and interpretations. First, we further test the hypothesis that lower cost of capital explains the valuation results by producing cost of equity estimates and test whether they have dropped 
for euro firms after 1998. We also provide additional evidence on the valuation effects by examining stock returns as an alternative to the Tobin's Q approach. Finally, we use the opinion poll results in Sweden prior to the country's EMU referendum as an explanatory variable in examining stock returns.

\subsection{The Euro and Firms' Cost of Equity Capital}

In the literature, there are two methods of computing the cost of equity capital. The first method is based on past stock returns, and calculates the cost of equity capital as the average realized return over the current year. This methodology relies on an asset pricing model to compute market-adjusted returns, and assumes that realized returns are a proxy for expected returns. Fama and French (1997) find that estimates of cost of equity capital for industries are very imprecise, with standard errors of more than 3 percent. These errors are due to uncertainty regarding the true factor risk premiums, and they can be larger when estimating firms' cost of equity capital. Moreover, Elton (1999) shows that realized return are a very biased estimate of expected returns.

A second method consists of estimating the cost of equity based on current stock prices and analyst earnings forecasts. Easton, Taylor, Shroff, and Sougiannis (2002) summarize all these models, which are based on estimates of residual income based on earnings forecasts, and on backing out the cost of equity and expected growth rates using the current stock price. We follow a similar approach, by making the conservative assumption that the expected growth in earnings beyond a one-year horizon is zero, and then computing prices as:

$$
P_{t}=\frac{E\left[E P S_{t+1}\right]}{r_{t}^{e}}
$$

where $P_{t}$ is the current stock price, $E\left[E P S_{t+1}\right]$ is the earnings forecast, and $r_{t}^{e}$ is the cost of equity capital. Therefore, our estimate of $r_{t}^{e}$ is the forward-looking earnings yield $r_{t}^{e}=$ $\frac{E\left[E P S_{t+1}\right]}{P_{t}} .31$ We obtain one year ahead earnings estimates from $\mathrm{I} / \mathrm{B} / \mathrm{E} / \mathrm{S}$. We are able to estimate $r_{t}^{e}$ for 27,691 firm-year observations. We then estimate a panel regression of the cost of equity capital on the euro dummies and the standard controls.

\section{[INSERT TABLE 9]}


Model (1) in Table 9 shows that, without controlling for the short rate and the term spread, the cost of equity capital has dropped in weak-euro countries by 2.5 percent after 1998. This effect is not significant once we control for short-term rates and the term spread (model 2), which suggests that reductions in the cost of equity have been caused by reductions in the risk-free rate alone. Moreover, we do not find changes in the cost of equity in strongeuro firms after 1998, yet we have identified significant increases in Tobin's Q for those countries in our earlier results. These two regressions lead us to conclude that the valuation effects we identify cannot be ascribed to reductions in the cost of equity alone.

We replicate the Tobin's Q regressions controlling for changes in the cost of equity Because $r_{e}$ is endogenous in these regressions, we interpret our results in terms of correlations. In models (3) and (4) we show that cost of equity and Q are have a strong negative relationship as expected (coefficient of -0.921 , significant at the 1 percent level). However, even after controlling for the cost of equity, the euro-country dummies are still significant (5.7 percent increase in strong-euro countries, and 11.5 percent increase in weak-euro countries), which suggests that either the forward looking earnings yield is not a good proxy for the cost of equity, or that reductions in the cost of capital are not the only source of valuation increases.

\subsection{Evidence Based on Stock Returns}

Our evidence above is based on changes in price levels (Tobin's Q) rather than changes in expected returns. Hong and Stein (2006) justify this choice in a study of local investment bias by arguing that when all changes in risk premia are permanent, price effects translate into very small expected return differentials. The expected return changes could be so small that they become statistically insignificant, no matter how large the actual price effect is.

Bearing the above argument in mind, we still try to provide additional evidence based on stock returns. To that end, we replicate the methodology in Henry's (2000) study of stock market liberalizations. We first construct within-country portfolios of monthly stock returns, classified by the ERB of the firms. That is, within each country, we construct three valueweighted portfolios: One portfolio contains all firms whose ERB is positive and significant. A second portfolio contains all firms whose ERB is negative and significant. The third portfolio contains all other firms, for which the currency exposure is not significant. Stock returns and 
market capitalization is from Datastream. We therefore have 132 monthly observations on $16 \times 3$ portfolios (a total of 6,336 observations). Henry (2000) defines the event window as the liberalization month plus the preceding six months. We consider May 1998 as the month of actual introduction of the euro, since it was then that it was decided which countries would join, and also consider a window of six moths (November 1997 to May 1998). We then regress monthly returns on event dummies, interacted with portfolio characteristics (ERBs) and country characteristics (euro membership and strong/weak classification). We also estimate country-fixed effects. Results are in Table 10. We also control for the MSCI World Index, and the MSCI Europe Index, as proxies for the market return under the assumption that European markets are integrated.

\section{[INSERT TABLE 10]}

The results in Table 10 confirm a strong market reaction to the introduction of the euro, with stock return increases that vary between 3.4 and 4.7 percent in euro countries. The cross-sectional evidence is similar to the results for Tobin's Q. Weak-EMU firms experience stock return increases of 5.3-5.6 percent, and among these stock returns are larger for firms with negative and significant ERB (increase of 7.8 percent). All results are significant at the 1 percent level, and there is a significant difference between positive and negative ERB firms in weak-euro countries ( $\mathrm{p}$-value 0.0012). In model (4), the joint value of the coefficients suggests an insignificant return in strong-euro firms, and in firms with positive exposure.

Overall, the evidence based on stock returns shows that the euro has increased shareholder returns for the firms which were supposed to enjoy ex-ante larger reductions in the cost of capital: Firms in weak-euro countries and firms with negative exposure to currency depreciations. The stock return evidence is consistent with our evidence using Tobin's Q as a dependent variable.

\subsection{Evidence Based on Poll Results in Sweden}

We can provide additional evidence based on the market reaction to news about the incorporation of a given country to the common currency. On September 14, 2003, Sweden held a referendum on whether the country should join the euro. ${ }^{32}$ The referendum took place 
despite the assassination of Foreign Minister Anna Lindh - an ardent supporter of Sweden joining the EMU - on September 10, 2003. The referendum produced a strong "no" vote to the euro, with a 56.1 percent opposition, and a turnout of 82 percent of those entitled to vote.

The Swedish referendum is a good laboratory to test the expected effects of the euro on Swedish companies following the results of the polls that were conducted before the actual vote took place. ${ }^{33}$ We obtain data on the results from every published opinion poll in Sweden between January 2000 and September 11, 2003, from Sinovate Temo, a Swedish polling firm. There are 211 observations. For each poll, we know the percent of yes/no/undecided votes, and the day when the results were published. In 25 percent of the polls, the percent of "yes" votes exceeds the percent of "no" votes. In 72 percent of the polls, the opposite is true. Note that, even in these cases, there must be a larger percent of undecided voters in some polls (this happens in 23 out of 211 polls). In the last month preceding the September 14 vote, all polls predict the "no" to win, except for one single poll with a 50/50 split.

\section{[INSERT TABLE 11]}

We regress weekly stock returns for individual firms in Sweden on the domestic market return, the change in exchange rate between the euro and the US dollar, and two indicators of poll results. We control for the euro/dollar rate because it was argued ex-post that the reason for the result of the referendum was the weakness of the euro against the dollar in the months prior to the vote. The first indicator equals one if the percent of "yes" votes in an opinion poll increases relative to the previous one, zero otherwise. The second dummy variable equals one if the percent of "yes" votes in the poll exceeds the percent of "no" votes in the poll. We ignore undecided voters, and use only the weeks when an opinion poll was published. We interact these dummy variables with the sign of the ERB of each firm. Results are in Table 11. In model (1) we show a positive market reaction whenever the percentage of "yes" votes increase with respect to the preceding poll. Such a reaction is however negative ( -5.6 percent combined) for positive-ERB firms, i.e. for firms that would benefit from weak krona. We also find that firm returns deteriorate as the euro depreciates with respect to the dollar. 
In model (2) we show the effect of a "yes" vote being ahead in the polls. It results on a positive return for negative-ERB firms, and a negative return for positive-ERB firms. Firms that would be harmed by a depreciation of the krona display a positive return of 0.8 percent per week (significant at the 10 percent level), while firms that benefit from depreciations show a negative return of 1.7 per week.(significant at the 5 percent level). These results confirm our prior findings.

\section{Conclusion}

Economic and Monetary Union and the adoption of a common currency is a major social experiment that also has significant economic and financial implications. This article is a first attempt to study the effects of the euro on firm value using corporate-level data. We

show that valuations for firms from the euro countries that devalued their currencies during the ERM-crisis in 1992-93 have grown by 17.1 percent in the period 1998-2004 compared to the five non-euro countries. The strong results for the weak-euro countries throughout the whole paper are consistent with the theoretical results of Alesina and Barro (2002), who show that currency unions should be most beneficial for countries that have suffered from credibility problems in their exchange rate and monetary policies. After we control for the level of short-term interest rates and the term spread, the increase in valuations decreases to 14.9 percent for firms from the weak-euro countries. Lower real interest rates and improved monetary policy credibility are thus important ingredients in explaining the positive impacts that the euro has caused on corporate valuations, but by no means the most important reason for the increase in corporate valuations.

It seems that ruling out the periodic currency devaluations that the weak-euro countries experienced when they had independent currencies is a major factor in explaining the positive valuation effects. This conclusion is at odds with the view that currency risks are not that important. Maybe part of the reason that most studies find exposures to currency fluctuations to be of secondary importance is that currency risks are indeed economically insignificant most of the time, but become very important when there are dramatic changes in exchange rates - typically large currency devaluations. This view is very consistent with 
our strong results for firms from the weak-euro countries.

Furthermore, we show that the cost of equity has also declined for firms from the weakeuro countries. However, this decline in cost of equity can explain only a part of the increase in corporate valuations. Thus we conclude that valuations have also increased because cash flows are expected to increase in the future.

Our paper documents a positive market reaction to the common currency. An interesting question is whether such a valuation effect has translated into more real effects. For instance, the Tobin's Q theory of investment predicts that increases in Q should be accompanied by increases in firm investment. Indeed Bris et al. (2006) provide results documenting a significant increase in investments for firms from the weak-euro countries in the period 1998-2004.

Do our results imply that all European countries should join the EMU? It might be tempting to say yes, but as in economics in general, the right answer should be: It depends. We have shown in this paper that the prior strength or weakness of a country's currency is decisive. If a candidate country's currency has experienced regular devaluations, then the answer should be yes. If the candidate country's currency has been stable, there seems to be very small benefits in joining the euro, at least on a corporate level. 


\section{A Appendix: Calculation of Forward Rate Differentials}

Following Hardouvelis et al. (2006), we calculate monthly forward rate differentials from swap rates between fixed and floating rate government bonds. We calculate 8-year forward rates in 2 years, and then calculate spreads for each country with respect to Germany, as $s_{i t}=\ln \left(1+f_{i, 2, t}^{8}\right)-\ln \left(1+f_{G E, 2, t}^{8}\right)$, where $s_{i t}$ is the forward rate spread for country $i$ in month

$t$, and $f_{i, 2, t}^{8}$ and $f_{G E, 2, t}^{8}$ are respectively the 8-year forward rates in 2 years for country $i$ and Germany (in Hardouvelis et al. (2006) spreads are calculated as $f_{i, 2, t}^{8}-f_{G E, 2, t}^{8}$; we do not find any difference in the results using either approach). As in Hardouvelis et al. (2006), we use the spread between the German forward rate and the ECU forward rate as a measure of the German spread. Moreover, we adjust for market conventions on national swap markets. In all countries in the sample coupons are paid annually, except for Ireland and the UK, where they are paid semiannually. We annualize interest rates in both countries. We additionally convert swap yields to 360 days in Belgium, Ireland, and the UK, where the convention is 365 day-years. Swap data is from Datastream.

\section{B Appendix: Exchange Rate Exposure Calculation}

We characterize firms by their responses to exchange rate movements. To that end, we calculate exchange rate betas for the firms in our sample. In this section we describe the procedure.

A commonly used method of calculating a firm's exposure to currency risk is to estimate the following regression:

$$
R_{i j t}=\alpha_{i}+\varpi_{i} R_{m t}^{j}+\beta_{i}^{x} R_{x t}^{j}++u_{i j t}
$$

where $R_{i j}$ is the stock return of firm $i$ in country $j, R_{m}^{j}$ is the monthly return on the domestic market portfolio in country $j, R_{x}^{j}$ is the monthly change in the exchange rate in country $j$, and the $\beta_{i}^{x}$ 's are then measures of currency exposure. Such an approach is used by Jorion (1990), Bodnar and Gentry (1993), and Amihud (1994). Jorion (1991) uses a version of this two-factor model, in which the return of the market portfolio is the first factor and the component of innovations in the exchange rate that is orthogonal to the market return is 
the second factor. However the procedure affects only the estimates of the market beta, not the exchange rate exposures. Therefore, we follow the simple method of Jorion (1990). We estimate the model in (3) using monthly data from January 1992 through December $1994 .^{34}$ We purposely choose an estimation period that is before our sample period, in order to avoid potential endogeneity problems.

We calculate exchange rate betas (ERBs) with respect to the euro. Although the euro existed only after January 1, 1999, Datastream computes a synthetic euro rate based on the weights each currency has in the real euro. The exchange rates are expressed as units of domestic currency per euro. Because some firms lack stock return data before 1995, the ERB sample is smaller than our original sample

[INSERT TABLE B.1] 


\section{Appendix: Variable Definitions}

\begin{tabular}{|c|c|}
\hline Variable & $\mathrm{m}$ \# refers to Wor \\
\hline Tobin's Q & $\begin{array}{l}\text { Market value of common equity (item 08001) + Total assets (item 02999) } \\
\text { Book value of common equity (item 03501)] / Total assets (item 02999) }\end{array}$ \\
\hline Global industry-adjusted & Tobin's Q minus the median two-digit SIC code industry Tobin's Q. The \\
\hline Tobin's Q & $\begin{array}{l}\text { median } \mathrm{Q} \text { is calculated using all firms from all the countries with available } \\
\text { data on } \mathrm{Q} \text { in Worldscope (irrespective of whether the countries and firms } \\
\text { are included in the regression sample). }\end{array}$ \\
\hline Sales & $\begin{array}{l}\text { Tet sales (item 01001) expressed in thousands of euro (using a synthetic } \\
\text { uro exchange rate prior to January 1, 1999). }\end{array}$ \\
\hline EBITDA/assets & $\begin{array}{l}\text { Earnings before interest, taxes, and depreciation (item 18198) / Total assets } \\
\text { (item 02999) }\end{array}$ \\
\hline NPPE/assets & t property, plant, and equipment (item 02501) /assets \\
\hline Leverage & Total debt $t_{t-1}\left(\right.$ item 03255) / Total assets $_{t-1}($ item 02999) \\
\hline CAPEX / assets & Capital Expenditures (item 04601) / Total Assets (item 02999) \\
\hline R\&D Expenses /assets & R\&D Expenses (item 01201) / Total Assets (item 02999) \\
\hline GDP growth & Annual real growth rate in GDP \\
\hline GDP/capita & al GDP per capita, e \\
\hline $\begin{array}{l}\text { Relative change in } \\
\text { domestic/USD exchange }\end{array}$ & 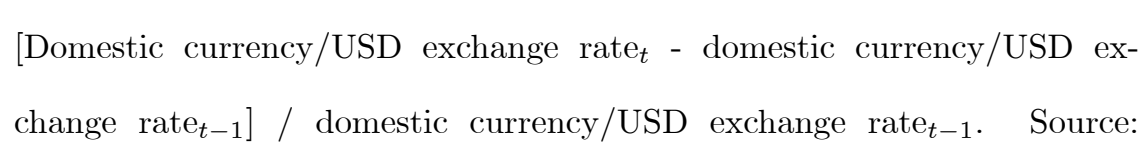 \\
\hline rate & Economist Intelligence Unit \\
\hline Short-term interest rate & 6-month treasury bill yield. Source: Economist Intelligence Unit \\
\hline Term spread & $\begin{array}{l}\text { Difference in yields between 10- year government bond and 6-month trea- } \\
\text { sury bill. Source: Economist Intelligence Unit }\end{array}$ \\
\hline $\begin{array}{l}\text { Government budget } \\
\text { deficit }\end{array}$ & $\begin{array}{l}\text { Domestic government budget deficit as a fraction of GDP. Source: Econo- } \\
\text { mist Intelligence Unit }\end{array}$ \\
\hline Government debt/GDP & $\begin{array}{l}\text { Total domestic government debt / GDP. Source: Economist Intelligence } \\
\text { Unit }\end{array}$ \\
\hline Inflation rate & $\begin{array}{l}\text { The inflation rate as measured by the annual change in CPI. Source: Econo- } \\
\text { mist Intelligence Unit }\end{array}$ \\
\hline Long-term interest rate & 10-year government bond yield. Source: Economist Intelligence Unit \\
\hline
\end{tabular}




\section{References}

Adler, M., and B. Dumas, 1983, International Portfolio Choice and Corporation Finance: A Synthesis, Journal of Finance 38, 925-984.

Alesina, A., and R. J. Barro, 2002, Currency Unions, Quarterly Journal of Economics $117,409-436$.

Allayannis, G., U. Lel, and D. P. Miller, 2004, Corporate Governance and the Hedging Premium around the World, working paper.

Allayannis, G., and J. P. Weston, 2001, The Use of Foreign Currency Derivatives and Firm Market Value, The Review of Financial Studies 14, 243-276.

Amihud, Y., 1994, Exchange Rates and the Valuation of Equity Shares, in Y. Amihud and R M. Levich (eds.), Exchange Rates and Corporate Performance (Irwin, New York), 49-59.

Baldwin, R., 2006, In or Out: Does It Matter? An Evidence-Based Analysis of the Euro's Trade Effects. London, Centre for Economic Policy Research.

Bartram, S. and G. A. Karolyi, 2006, The Impact of the Introduction of the Euro on Foreign Exchange Risk Exposures, Journal of Empirical Finance 13, 519-549.

Bekaert, G., and C. Harvey, 1995, Time-Varying World Market Integration, Journal of Finance 50, 403-444.

Bertrand, M., E. Duflo, and S. Mullainathan, 2004, How Much Should We Trust Differences-in-Differences Estimates?, Quarterly Journal of Economics 119, 249-275.

Bodart, V., and Paul R., 1999, Exchange Rate Regime, Volatility and International Correlations of Bond and Stock Markets, Journal of International Money and Finance 18, 133-151. 
Bodnar, G. M., and W. Gentry, 1993, Exchange rate exposure and industry characteristics: Evidence from Canada, Japan, and the US, Journal of International Money and Finance $12,29-45$.

Bris, A., Y. Koskinen, and M. Nilsson (2006), The Real Effects of the Euro: Evidence from Corporate Investments, Review of Finance 10, 1-37.

Bun, M. J.G., and F.J.G.M. Klaassen, 2007, The Euro Effect on Trade is not as Large as Commonly Thought, forthcoming , Oxford Bulletin of Economics and Statistics 69, 473-496.

Cooper, I., and E. Kaplanis, 1994, Home Bias in Equity Portfolios, Inflation Hedging, and International Capital Market Equilibrium, Review of Financial Studies 7, 45-60.

Dahlquist, M., and G. Robertsson, 2001, Direct Foreign Ownership, Institutional Investors, and Firm Characteristics, Journal of Financial Economics 59, 413-440.

Daines, R., 2001, Does Delaware Law Improve Firm Value?, Journal of Financial Economics $62,525-558$.

Desai, M., A. Dyck, and L. Zingales, 2007, Theft and Taxes, Journal of Financial Economics 84, 591-623.

De Santis, G., and B. Gerard, 1998, How Big is the Premium for Currency Risk?, Journal of Financial Economics 49, 375-412.

De Santis, Giorgio, Bruno Gerard, and Pierre Hillion, 2003, The Relevance of Currency Risk in the EMU, Journal of Economics and Business 55, 427-462.

Dumas, B., and B. Solnik, 1995, The World Price of Foreign Exchange Risk, Journal of Finance 50, 445-479.

Easton, P., G. Taylor, P. Shroff, and Theodore Sougiannis, 2002, Using Forecasts of Earnings to Simultaneously Estimate Growth and the Rate of Return on Equity Investment, Journal of Accounting Research 40. 657-676. 
Elton, E. J., 1999, Expected Return, Realized Return, and Asset Pricing Tests, Journal of Finance 54, 1199.

Erickson, T., and T. M. Whited, 2000, Measurement Error and the Relationship between Investment and "q", Journal of Political Economy 108, 1027-1057.

Errunza, V., and E. Losq, 1985, International Asset Pricing Under Mild Segmentation: Theory and Test, Journal of Finance 40, 105-124.

Estrella, A., and G. A. Hardouvelis, 1991, The Term Structure as Predictor of Real Economic Activity, Journal of Finance 46, 555-576.

Estrella, A., and F. S. Mishkin, 1997, The Predictive Power of the Term Structure of the Interest Rates in Europe and the United States: Implications for the European Central Bank, European Economic Review 41, 1375-1401.

Eun, C. S. and S. Janakiramanam, 1986, A Model of International Asset Pricing with a Constraint on the Foreign Equity Ownership, Journal of Finance 41, 897-914.

Fama, E. F., 1990, Term Structure Forecasts of Interest Rates, Inflation and Real Returns, Journal of Monetary Economics 25, 56-76.

Fama, E. F., and K. R. French, 1997, Industry costs of equity, Journal of Financial Economics 43, 153-193.

Favero, C. A., F. Giavazzi, F. Iacone, and G. Tabellini, 1997, Extracting Information from Asset Prices: The Methodology of EMU Calculators, European Economic Review 44, 1607-1632.

French, K., and J. Poterba, 1991, Investor Diversification and International Equity Markets, American Economic Review 81, 222-226.

Geczy C., B. A. Minton, and C. Schrand, 1997, Why Firms Use Currency Derivatives, Journal of Finance 52, 1323-1354.

Glick, R., and A. Rose, 2002, Does a Currency Union Affect Trade? The Time-Series Evidence, European Economic Review 46, 1125-1151. 
Hardouvelis, G. A., D. Malliaropoulos, and R. Priestley, 2006, EMU and European Stock Market Integration, Journal of Business, 79, 365-392.

Henry, P. B., 2000, Stock Market Liberalization, Economic Reform, and Emerging Market Equity Prices, Journal of Finance 55, 529-564.

Hermalin, B., and M. Weisbach, 1981, The Effects of Board Composition and Direct Incentives on Firm Performance, Financial Management 20, 101-112.

Hong H., and J. Stein, 2006, The Only Game in Town: Stock-Price Consequences of Local Bias, working paper.

Jorion, P., 1990, The Exchange Rate Exposure of US Multinationals, Journal of Business $63,331-345$.

Jorion, P., 1991, The Pricing of Exchange Rate Risk in the Stock Market, Journal of Financial and Quantitative Analysis 26, 363-376.

Jorion, P., and Frederic S. Mishkin, 1991, A Multi-Country Comparison of Term-Structure Forecasts at Long Horizons, Journal of Financial Economics 29, 59-80.

Kang, J.K., and R. Stulz, 1997, Why Is There a Home Bias? An Analysis of Foreign Portfolio Equity Ownership in Japan, Journal of Financial Economics 46, 3-28.

La Porta, R., F. Lopez-de-Silanes, A. Shleifer, and R. Vishny, 1998, Law and Finance, Journal of Political Economy 106, 1113-1155.

La Porta, R., F. Lopez-de-Silanes, A. Shleifer, and R. Vishny, 2002, Investor Protection and Corporate Valuation, Journal of Finance 57, 1147-1170.

Lang, L., and R. Stulz, 1994, Tobin's Q, diversification, and firm performance, Journal of Political Economy 102, 1248-1280.

Lewis, K., 1999, Trying to Explain Home Bias in Equities and Consumption, Journal of Economic Literature 37, 571-608. 
McConnell, J., and H. Servaes, 1990, Additional Evidence on Equity Ownership and Corporate Value, Journal of Financial Economics 27, 595-612.

Mishkin, F. S., 1990, The Information in the Longer Maturity Term Structure about Future Inflation, Quarterly Journal of Economics 105, 815-828.

Morck, R., A. Shleifer, and Robert W. Vishny, 1988, Management Ownership and Market Valuation: An Empirical Analysis, Journal of Financial Economics 20, 293-315.

Mundell, R., 1961, A Theory of Optimum Currency Areas, American Economic Review $51,509-517$.

Ohlson, J. A., and B. E. Juettner-Nauroth, 2005, Expected EPS and EPS Growth as Determinants of Value, Review of Accounting Studies 9, 3-30.

Persson, T., 2001, Currency Unions and Trade: How Large Is the Treatment Effect?, Economic Policy 16, 335-48.

Rajan, R.G., and L. Zingales, 2003, Banks and Markets: The Changing Character of European Finance, European Central Bank 2nd Annual Conference.

Rose, A., 2000, One Money, One Market: Estimating the Effect of Common Currencies on Trade, Economic Policy 15, 9-48.

Rose, A., and E. van Wincoop, 2001, National Money as a Barrier to Trade: The Real Case for Monetary Union, American Economic Review 91, 386-390.

Rouwenhorst, K. G., 1999, European Equity Markets and EMU: Are the Differences between Countries Slowly Disappearing?, Financial Analyst Journal 55, 57-64.

Scott, H. S., 1998, When the Euro Falls Apart, International Finance 1:2, 207-228.

Stulz, R., 1999, Globalization of Capital Markets and the Cost of Capital, Journal of Applied Corporate Finance, Fall , 8-25.

Tesar, L., and I. Werner, 1995, Home Bias and High Turnover, Journal of International Money and Finance 14, 467-492. 
Yermack, D., 1996, Higher Market Valuation of Companies with a Small Board of Directors, Journal of Financial Economics 40, 185-211. 


\section{Notes}

*. We thank Malcolm Baker, Söhnke Bartram, Judy Chevalier, Mariassunta Giannetti, Leo de Haan, Huong Higgins, Massimo Massa, Darius Miller, Geert Rouwenhorst, Matthew Spiegel, Rohan Williamson, Bernard Yeung, and audiences at Stockholm School of Economics, Bank of Finland, NYU Salomon Center Conference on the Euro, Yale School of Management, the NBER Summer Institute in Cambridge, Darden, Bank of Sweden, Uppsala, Vanderbilt, Norwegian School of Economics, Purdue, University of Arizona, University of Utah, WPI, the ECB-CFS Workshop in Helsinki, the 2003 International Finance Conference in Atlanta, the 2003 Global Investment Forum in Banff, the 2003 SNEE Symposium in Mölle, the 2003 WFA Meetings in Los Cabos, Bank of Norway, and Stockholm Institute for Financial Research for helpful comments. We also thank the editor (Robert McDonald) and two anonymous referees for helpful comments and suggestions; and Vanessa Janowski and Teresa Kwon for excellent research assistance. An earlier version of this paper has been circulated under the title of "The Euro Is Good After All: Evidence from Corporate Valuations." The project was initiated while Nilsson was visiting the International Center for Finance (ICF) at Yale School of Management. He wishes to thank the ICF for its hospitality during his stay. This article is produced as a part of a CEPR project on Understanding Financial Architecture: Legal Framework, Political Environment and Economic Efficiency, funded by the European Commission under the Human Potential - Research Training Network program (Contract No. HPRN-CT-2000-00064). The authors are responsible for all remaining errors.

†. IMD, Yale International Center for Finance and ECGI. Address for correspondence: IMD, Chemin de Bellerive 23, P.O. Box 915, CH-1001 Lausanne, Switzerland. Tel: +41 21 6180111; fax: +41 21618 0707, email: arturo.bris@imd.ch.

‡. Boston University School of Management and CEPR. Address for correspondence: Boston University School of Management, 595 Commonwealth Avenue, Boston, MA 02215. Phone: (617)353-9775; Fax: (617)353-6667; E-Mail: yrjo@bu.edu. 
$\S$. University of Colorado at Boulder. Address for correspondence: University of Colorado at Boulder - Department of Finance, Campus Box 419, Boulder, CO 80309. Phone: (303) 492-2289; E-mail: Mattias.Nilsson@colorado.edu.

1. Throughout this paper, when we refer to the EMU countries, we mean the countries that have entered phase III of the EMU, i.e. adopted the euro as their currency. So, for example, Sweden, which has entered phases I and II of the EMU, but has not adopted the euro as its currency, is not classified as an EMU country.

2. See The Wall Street Journal, "Italy's Leader Stands Accused Of Euro-Heresy," 16 January 2002 .

3. Greece adopted the euro as its currency in January 1, 20001, two years after the other countries. Greece is excluded from the analysis, because it is difficult to determine the correct event year - speculations about Greece joining the EMU started already in January 1999.

4. ERM stands for Exchange Rate Mechanism, the previous currency arrangement in Europe. The participating countries pegged their currencies to ECU (European Currency Unit), the precursor of the euro.

5. Geczy, Minton, and Schrand (1997) find that among the Fortune 500 non-financial companies, 52.1 percent use currency derivatives. Allayannis and Weston (2001) analyze 720 large non-financial firms in the US in the period 1990-1995 and report that only 37 percent hedge their currency exposure. Among the firms in their sample with foreign sales, the proportion of hedgers increases to 60 percent.

6. De Santis, Gerard, and Hillion (2003) argue that eliminating intra-European currency risks may have only had a small economic impact for European corporations. Bartram and Karolyi (2006) show that due to the introduction of the euro, the market risk has been significantly reduced implying that currency risks have been a major non-diversifiable risk in Europe.

7. For home equity bias, see French and Poterba (1991), Cooper and Kaplanis (1994), and Tesar and Werner (1995). Lewis (1999) provides an extensive recent survey of the 
literature. For partial segmentation models, where local risks are priced, see Errunza and Losq (1985) and Eun and Janakiramanan (1986). Rouwenhorst (1999) finds that during the 1990s, country factors were more important than industry factors in determining stock returns in Europe. In contrast, Hardouvelis, Malliaropoulos, and Priestley (2006) find that European equity markets became more integrated towards the end of the 1990s.

8. Already in January 1999, speculations started that Greece would adopt the euro. For example, the Financial Times wrote on January 21, 1999, that "Rising confidence in Greece's chances of becoming the 12th member of the euro club drove prices on the Athens stock exchange to record levels this month." In robustness tests, we confirm this by finding a significant run-up in the values of Greek firms in 1999. Moreover, when performing an analysis of interest swap spreads similar to the one below for Greece, we find that swap spreads in Greece are not statistically different from the average weak-EMU country in January 1999. However, Greece's application to join the EMU was officially accepted on June 19, 2000. Thus determining the correct event year for Greece is difficult. The effect of the inclusion of Greece in the sample depends greatly on which time period we choose as the date of introduction of the euro in that country.

9. Denmark has maintained a very tight peg first with the German mark and from January 1999 with the euro $(€ 1=\operatorname{DKr} 7,460.38 \pm 2.25 \%)$. The reason we classify Denmark as a non-euro country despite the tight link with the krone and euro, is that a unilateral peg does not provide the same kind of commitment mechanism to a monetary policy that a currency union would provide (see Alesina and Barro, 2002, for further discussion). Our results, however, are robust to including Denmark as a euro country (results available from the authors upon request).

10. Imposing a survivorship bias throughout the whole period would bias our results towards finding a positive euro valuation effect.

11. German mark was the anchor currency of the European exchange rate mechamism (ERM). 
12. In the autumn of 1992, a wave of speculative attacks hit the European exchange rate mechanism (ERM) and its periphery. Before the end of the year, five countries (Finland, Italy, Norway, Sweden, and the UK) had floated their currencies and as a result their currencies experienced large devaluations. Three countries (Ireland, Portugal, and Spain) where forced to devalue their currencies in 1992-93 while maintaining a membership in ERM. The devaluation for Ireland was smaller than for the other weak-euro countries and an argument could be made that Ireland should be classified as a strong-euro country. In unreported regression we show that our results remain qualitatively same even if we changed Ireland's classification.

13. Belgium and Luxembourg were in a currency union since 1992.

14. France and Belgium faced several speculative attacks during 1992-93, but these countries managed to maintain their "franc fort" policy without a devaluation.

15. This is precisely the reason why we do not classify Denmark as an EMU-country, even though Denmark has maintained a close peg with respect to the euro. However, we have run our main regressions with Denmark classified as a euro-country. The results remain qualitatively the same (results are not reported).

16. Eriksson and Whited (2000) have shown that the typical proxies for Tobin's Q do not work well as an explanatory variable in investment regressions. The reason is that marginal Q is substituted for average Q in empirical tests. However, Tobin's Q is a reasonable proxy for firm value, and it has been extensively used in the literature (Hermalin and Weisbach, 1981; Morck, Shleifer, and Vishny, 1988; Lang and Stulz, 1994; Yermack, 1996; La Porta, Lopez-de-Silanes, Shleifer, and Vishny, 1998; Daines, 2001).

17. Many firms in our sample have dual-class shares. For those, Worldscope reports the market capitalization of each share class, and the market capitalization of the entire company, which is computed as the total number of shares outstanding, other than preferred, times the stock price of the most widely-held class. La Porta et al. (2002) argue that as the most widely-held class usually does not carry voting rights, this computation removes any voting 
premium from the market value of the equity. In our case, as in theirs, this is an advantage more than a problem because we are interested in the pure valuation effect of the euro.

18. For more than two-thirds $(24,442)$ of our firm-year observations the fiscal year end is in December. Our results are robust to excluding firms for which the date of the fiscal year end is outside December or is not reported in Worldscope.

19. As a robustness check, we have estimated our main regressions with individual-year effects. The results (unreported) show an anticipation effect in 1997 in weak-euro countries, but also that the effect of the euro for strong-euro countries is concentrated in 1998.

20. Some countries, like Switzerland and the Netherlands, consistently display negative spreads.

21. We obtain the average spread by adding the intercept in the regression to the coefficients for the years 1996, 1997, and 1998 .

22. We have checked that our results are robust to excluding technology companies from the sample (unreported), that may distort the results in the post-euro period because of the technology bubble. The effects of the euro in weak-euro countries remain unchanged, while the effect of the euro on Tobin's Q in strong-euro countries is larger.

23. It could be argued that after the introduction of the euro the country-specific shortterm treasury rate is not risk-free for the countries with high debt/GDP-ratios (for example Belgium and Italy). However, the markets do not charge the high debt/GDP-countries higher rates.

24. Since the dependent variable is the industry-adjusted Q, we cannot take logarithms. Hence the euro-dummy coefficients cannot be interpreted as percentages.

25. Both findings are statistically significant at the 5 percent level.

26. The text of the Treaty is available at http://europa.eu.int/en/record/mt/top.html

27. Data on corporate tax rates in Europe are from KPMG Corporate Tax Rate Survey, 
$1995-2001$.

28. It should be noted that the resulting within-country change in tax rates does not take into account potential concurrent changes in tax deferrals and tax credits. Thus, our measure does not necessarily capture changes in the effective corporate tax rates. Furthermore, some countries like Germany, have a split-rate system that taxes differently earnings that are retained and earnings that are paid out. In such cases we use the highest tax-rate.

29. Our definition of "small" is of course relative to the median firm covered by Worldscope. Worldscope covers mostly the largest firms in a country.

30. Our overall findings do not change if we re-classify these three countries. In unreported regressions, we find that the increase in Tobin's Q is 5.3 percent for strong-euro countries and 10.1 percent for weak-euro countries, when we reclassify France and Belgium as weak countries and Ireland as a strong country.

31. As a robustness check, we have estimated the cost of equity capital using dividend yield forecasts, and our results are qualitatively similar. We have also attempted to collect data on expected growth rates to compute estimates of the cost of capital using the methodology in Ohlson and Juettner-Nauroth (2005). Because expected growth rates are often negative, we obtain negative estimates of the cost of equity for a large fraction of our sample firms.

32. Denmark also held a referendum on September 28, 2000. However, because the Danish krone has been pegged to the euro since January 1998, and Danish authorities confirmed that the peg would continue if the euro was rejected, the impact of the referendum on a firm's returns is more difficult to assess.

33. We thank an anonymous referee for suggesting the analysis in this section.

34. If there are fewer than 18 observations available per firm, we exclude it from the estimation. 
Table 1. Firm characteristics

The sample is an unbalanced panel of 4,242 firms (36,246 firm-years) from the Euro-countries (except Greece) and five Non-euro countries (Denmark, Norway, Sweden, Switzerland, and UK) with data available in Worldscope over the time period 1994-2004. See the Appendix for variable definitions. All variables are winsorized at the $1^{\text {st }}$ and $99^{\text {th }}$ percentile value of the total sample to reduce the influence of outliers.

\begin{tabular}{|c|c|c|c|c|c|c|c|c|c|c|c|c|c|c|c|c|}
\hline \multirow[b]{2}{*}{ Country } & \multirow[b]{2}{*}{ \# firms } & \multirow{2}{*}{$\begin{array}{c}\text { \# firm-year } \\
\text { observations }\end{array}$} & \multicolumn{2}{|c|}{ Tobin's Q } & \multicolumn{2}{|c|}{$\begin{array}{c}\text { Sales } \\
\text { (million euros) }\end{array}$} & \multicolumn{2}{|c|}{ EBITDA/TA } & \multicolumn{2}{|c|}{ NPPE/TA } & \multicolumn{2}{|c|}{ Leverage } & \multicolumn{2}{|c|}{ CAPEX/TA } & \multicolumn{2}{|c|}{$\mathrm{R} \& \mathrm{D} / \mathrm{TA}$} \\
\hline & & & Mean & Std. dev. & Mean & Std. dev. & Mean & Std. dev. & Mean & Std. dev. & Mean & Std. dev. & Mean & Std. dev. & Mean & Std. dev. \\
\hline Austria & 79 & 671 & 1.205 & 0.602 & 549.4 & $1,037.1$ & 0.108 & 0.076 & 0.369 & 0.217 & 0.249 & 0.168 & 0.062 & 0.054 & 0.006 & 0.014 \\
\hline Belgium & 101 & 909 & 1.375 & 0.781 & 949.8 & $2,438.7$ & 0.117 & 0.092 & 0.232 & 0.211 & 0.225 & 0.170 & 0.055 & 0.068 & 0.002 & 0.010 \\
\hline Finland & 100 & 915 & 1.357 & 0.732 & 971.4 & 2,586.6 & 0.141 & 0.087 & 0.368 & 0.232 & 0.266 & 0.181 & 0.072 & 0.066 & 0.013 & 0.027 \\
\hline France & 598 & 4,936 & 1.371 & 0.782 & $1,548.9$ & $4,419.2$ & 0.111 & 0.089 & 0.230 & 0.213 & 0.242 & 0.181 & 0.050 & 0.057 & 0.006 & 0.021 \\
\hline Germany & 535 & 4,741 & 1.643 & 1.077 & $1,530.1$ & $4,413.4$ & 0.119 & 0.104 & 0.321 & 0.218 & 0.211 & 0.196 & 0.064 & 0.065 & 0.009 & 0.025 \\
\hline Ireland & 41 & 380 & 1.396 & 0.716 & 935.6 & $1,603.8$ & 0.102 & 0.096 & 0.416 & 0.265 & 0.268 & 0.142 & 0.063 & 0.063 & 0.004 & 0.013 \\
\hline Italy & 175 & 1,589 & 1.261 & 0.682 & 2,115.6 & 4,829.5 & 0.089 & 0.081 & 0.245 & 0.213 & 0.283 & 0.174 & 0.042 & 0.053 & 0.004 & 0.013 \\
\hline Luxemburg & 11 & 85 & 1.447 & 1.039 & $1,499.4$ & $2,848.7$ & 0.143 & 0.121 & 0.252 & 0.258 & 0.145 & 0.143 & 0.035 & 0.052 & 0.000 & 0.001 \\
\hline Netherlands & 166 & 1,440 & 1.573 & 1.063 & $2,046.0$ & 4,927.7 & 0.140 & 0.095 & 0.328 & 0.234 & 0.237 & 0.172 & 0.065 & 0.055 & 0.006 & 0.020 \\
\hline Portugal & 73 & 578 & 1.127 & 0.572 & 567.3 & $1,143.3$ & 0.107 & 0.075 & 0.383 & 0.223 & 0.288 & 0.180 & 0.047 & 0.058 & 0.000 & 0.000 \\
\hline Spain & 138 & 1,256 & 1.328 & 0.690 & $1,528.1$ & $3,870.7$ & 0.108 & 0.074 & 0.380 & 0.248 & 0.224 & 0.165 & 0.047 & 0.054 & 0.001 & 0.009 \\
\hline All euro countries & 2,017 & 17,500 & 1.434 & 0.883 & $1,489.0$ & 4119.3 & 0.115 & 0.093 & 0.297 & 0.229 & 0.238 & 0.182 & 0.061 & 0.061 & 0.006 & 0.020 \\
\hline Denmark & 183 & 1,630 & 1.299 & 0.831 & 396.1 & $9,41.6$ & 0.098 & 0.093 & 0.289 & 0.228 & 0.256 & 0.173 & 0.052 & 0.057 & 0.007 & 0.024 \\
\hline Norway & 159 & 1,234 & 1.531 & 1.090 & 480.7 & $1,599.7$ & 0.098 & 0.116 & 0.344 & 0.290 & 0.306 & 0.210 & 0.079 & 0.084 & 0.009 & 0.031 \\
\hline Sweden & 201 & 1,659 & 1.631 & 1.057 & 1,107 & $2,761.5$ & 0.112 & 0.111 & 0.320 & 0.267 & 0.253 & 0.203 & 0.060 & 0.061 & 0.012 & 0.032 \\
\hline Switzerland & 169 & 1,551 & 1.451 & 0.930 & 1,234 & 3,308.6 & 0.114 & 0.083 & 0.367 & 0.240 & 0.260 & 0.162 & 0.047 & 0.043 & 0.016 & 0.031 \\
\hline United Kingdom & 1,513 & 12,672 & 1.549 & 1.108 & 786.6 & $2,723.8$ & 0.094 & 0.121 & 0.325 & 0.282 & 0.179 & 0.155 & 0.054 & 0.060 & 0.010 & 0.030 \\
\hline All non-euro countries & 2,225 & 18,746 & 1.526 & 1.070 & 798.0 & 2623.9 & 0.098 & 0.115 & 0.327 & 0.274 & 0.207 & 0.171 & 0.058 & 0.061 & 0.013 & 0.030 \\
\hline All countries & 4,242 & 36,246 & 1.481 & 0.985 & $1,131.6$ & 3445.7 & 0.106 & 0.105 & 0.312 & 0.254 & 0.222 & 0.177 & 0.060 & 0.061 & 0.009 & 0.026 \\
\hline
\end{tabular}


Table 2: Convergence of Forward Rates

We calculate monthly forward rate differentials from swap rates between fixed and floating government bonds. We calculate 8-year forward rates in 2 years, and then calculate spreads for each country with respect to Germany, as $s_{i t}=\ln \left(1+f_{i, 2, t}^{8}\right)-\ln \left(1+f_{G E, 2, t}^{8}\right)$, where $s_{i t}$ is the forward rate spread for country i in month $t$, and $f_{i, 2, t}^{8}$ and $f_{G E, 2, t}^{8}$ are respectively the 8-year forward rates in 2 years for country $i$ and Germany. We use the spread between the German forward rate and the ECU forward rate as a measure of the German spread. Swap data is from Datastream. As in Hardouvelis (2001), we adjust for market conventions on national swap markets. In all countries in the sample coupons are paid annually, except for Ireland and the UK, where they are paid semiannually. We annualize interest rates in both countries. We additionally convert swap yields to a 360 days in Belgium, Ireland, and the UK, where the convention is 365 day-years. We then regress the resulting forward rate differentials on time dummies. We construct time dummies as follows, for each year $T, T=1996, \ldots 2000$, the variable $I_{T}=1$ for $t \geq T$, where $t$ is the date-month and year--of the corresponding observation, zero otherwise.

\begin{tabular}{|c|c|c|c|c|c|c|c|c|}
\hline & \multicolumn{2}{|c|}{ Total Sample } & \multicolumn{2}{|c|}{ No EMU countries } & \multicolumn{2}{|c|}{ Weak EMU countries } & \multicolumn{2}{|c|}{$\begin{array}{l}\text { Strong EMU } \\
\text { countries }\end{array}$} \\
\hline & Estimate & t-stat & Estimate & t-stat & Estimate & t-stat & Estimate & t-stat \\
\hline Intercept & $0.0101 * * *$ & 13.86 & $0.0913 * * *$ & 22.21 & $0.1459 * * *$ & 28.91 & $0.0160 * * *$ & 13.48 \\
\hline 1996 and After & $-0.0052 * * *$ & -6.73 & $-0.0187 * * *$ & -3.81 & $-0.0652 * * *$ & -9.53 & $-0.0084 * * *$ & -6.15 \\
\hline 1997 and After & $-0.0026 * * *$ & -7.06 & $-0.0133 * * *$ & -3.11 & $-0.0549 * * *$ & -10.82 & $-0.0031 * * *$ & -3.51 \\
\hline 1998 and After & $-0.0008 * *$ & -2.38 & -0.0056 & -1.27 & $-0.0231 * * *$ & -9.58 & $-0.0044 * * *$ & -5.29 \\
\hline 1999 and After & -0.0002 & -0.64 & 0.0048 & 1.20 & -0.0018 & -1.00 & $0.0013 * *$ & 2.02 \\
\hline 2000 & -0.0003 & -1.08 & $-0.0148 * * *$ & -4.41 & -0.0004 & -0.22 & 0.0001 & 0.26 \\
\hline Country - Fixed Effects & YES & & YES & & YES & & YES & \\
\hline Adjusted R2 & 0.559 & & 0.704 & & 0.871 & & 0.633 & \\
\hline Number of Observations & 1,016 & & 343 & & 336 & & 337 & \\
\hline
\end{tabular}


Table 3. Average Tobin's Q ratios before and after the introduction of the euro: Euro countries vs. non-euro countries

The sample is an unbalanced panel of 4,242 firms from the Euro-countries (except Greece) and five Non-euro countries (Denmark, Norway, Sweden, Switzerland, and UK) with available data in Worldscope over the time period 1994-2004. The table displays the average Tobin's Q for the pre-euro time period (1994-1997) and the post-euro time-period (1998-2004), respectively. Tobin's Q is calculated annually for each firm as the sum of the market value of equity and book value of total liabilities divided by the book value. Alternatively, in Panel B, we also adjust this Q measure for each firm by deducting the annual median Q for all firms in the Worldscope universe within the same two-digit SIC code industry. The euro-countries classified as weak (i.e., countries with a recent currency crisis) are: Finland, Italy, Ireland, Portugal and Spain. The annual Tobin's Q ratios are winsorized at the $1^{\text {st }}$ and $99^{\text {th }}$ percentile value of the total sample to reduce the influence of outliers. For the reported t-tests, *, **, and ***, indicates significance at the $10 \%, 5 \%$, and $1 \%$-levels, respectively.

Panel A: Unadjusted Tobin’s Q

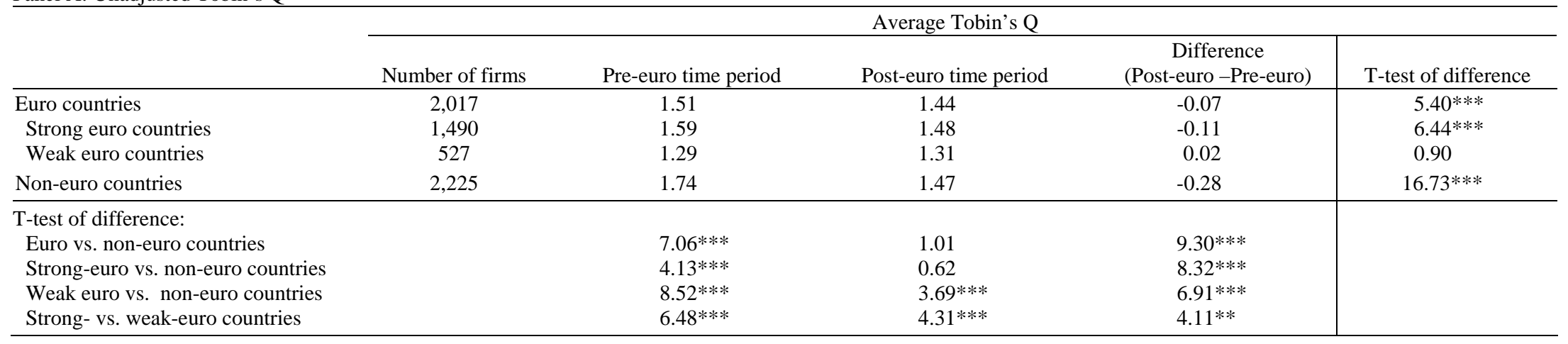

Panel B: Global industry-adjusted Tobin’s Q

Average global industry-adjusted Tobin's $Q$

\begin{tabular}{|c|c|c|c|c|c|}
\hline & \multicolumn{5}{|c|}{ Average global industry-adjusted Tobin’s Q } \\
\hline & Number of firms & Pre-euro time period & Post-euro time period & $\begin{array}{c}\text { Difference } \\
\text { (Post-euro-Pre-euro) }\end{array}$ & T-test of difference \\
\hline Euro countries & 2,017 & 0.22 & 0.29 & 0.07 & $6.74 * * *$ \\
\hline Strong euro countries & 1,490 & 0.29 & 0.35 & 0.06 & $3.77^{* * *}$ \\
\hline Weak euro countries & 527 & 0.02 & 0.20 & 0.18 & $7.79 * * *$ \\
\hline Non-euro countries & 2,225 & 0.41 & 0.29 & -0.12 & $7.05^{* * *}$ \\
\hline \multicolumn{6}{|l|}{ T-test of difference: } \\
\hline Euro vs. non-euro countries & & $6.29 * * *$ & 0.80 & $9.62 * * *$ & \\
\hline Strong-euro vs. non-euro countries & & $3.56^{* * *}$ & $2.17 * *$ & $7.36^{* * *}$ & \\
\hline Weak euro vs. non-euro countries & & $7.96^{* * *}$ & $2.48^{* * *}$ & $8.20 * * *$ & \\
\hline Strong- vs. weak-euro countries & & $5.94 * * *$ & $4.02^{* * *}$ & $3.65^{* * *}$ & \\
\hline
\end{tabular}


Table 4. The introduction of the euro and corporate valuations: Main regression results

The sample is an unbalanced panel of 4,242 firms from the Euro-countries (except Greece) and five Non-euro countries (Denmark, Norway, Sweden, Switzerland, and UK) with complete data in Worldscope over the time period 1994-2004. The dependent variable is the log of Tobin's Q in columns (1) - (4), and is the global industry-adjusted Tobin's Q in columns (5) - (8). Estimation by OLS with fixed firm and year effects. All firm-level variables are winsorized at the $1^{\text {st }}$ and $99^{\text {th }}$ percentile value of the total sample to reduce the influence of outliers. The post-euro time period is defined as the years 1998-2004. The eurocountries classified as weak (i.e., countries with a recent currency crisis) are: Finland, Italy, Ireland, Portugal and Spain. See the Appendix for other variable definitions. Panel A reports the regression estimates using all individual years in the panel. Panel B reports the estimation results from a regression model where the panel is reduced to two-periods by averaging the data before and after the introduction of the euro. Standard errors robust to clustering on country level are reported within brackets. *, **, and ${ }^{* * *}$, indicates significance at the $10 \%, 5 \%$, and $1 \%$-levels, respectively. 
Panel A: Full panel regressions

\begin{tabular}{|c|c|c|c|c|c|c|c|c|}
\hline \multirow[b]{2}{*}{ Explanatory variable: } & \multicolumn{2}{|c|}{$\begin{array}{c}\text { Dependent variable: } \\
\text { Log(Tobin’s Q) }\end{array}$} & \multicolumn{2}{|c|}{$\begin{array}{c}\text { Dependent variable: } \\
\text { Global industry-adjusted } \\
\text { Tobin’s Q }\end{array}$} & \multicolumn{2}{|c|}{$\begin{array}{c}\text { Dependent variable: } \\
\text { Log(Tobin’s Q) }\end{array}$} & \multicolumn{2}{|c|}{$\begin{array}{c}\text { Dependent variable: } \\
\text { Global industry-adjusted } \\
\text { Tobin's Q }\end{array}$} \\
\hline & $(1)$ & $(2)$ & (3) & $(4)$ & (5) & (6) & $(7)$ & $(8)$ \\
\hline Euro country x post-euro dummy & $\begin{array}{l}0.090^{* *} \\
{[0.031]}\end{array}$ & & $\begin{array}{l}0.137^{* *} \\
{[0.050]}\end{array}$ & & $\begin{array}{l}0.078^{* *} \\
{[0.030]}\end{array}$ & & $\begin{array}{l}0.121^{* *} \\
{[0.053]}\end{array}$ & \\
\hline Strong euro country x post-euro dummy & & $\begin{array}{c}0.057 * * \\
{[0.027]}\end{array}$ & & $\begin{array}{l}0.091^{*} \\
{[0.046]}\end{array}$ & & $\begin{array}{l}0.061^{*} \\
{[0.033]}\end{array}$ & & $\begin{array}{c}0.097 \\
{[0.058]}\end{array}$ \\
\hline Weak euro country x post-euro dummy & & $\begin{array}{c}0.171^{* * *} \\
{[0.025]}\end{array}$ & & $\begin{array}{c}0.251^{* * *} \\
{[0.043]}\end{array}$ & & $\begin{array}{c}0.128 * * * \\
{[0.031]}\end{array}$ & & $\begin{array}{c}0.191 * * * \\
{[0.063]}\end{array}$ \\
\hline Log (Sales) & $\begin{array}{c}-0.048 * * * \\
{[0.010]}\end{array}$ & $\begin{array}{c}-0.048^{* * *} \\
{[0.010]}\end{array}$ & $\begin{array}{c}-0.140 * * * \\
{[0.028]}\end{array}$ & $\begin{array}{c}-0.141 * * * \\
{[0.028]}\end{array}$ & $\begin{array}{c}-0.049 * * * \\
{[0.010]}\end{array}$ & $\begin{array}{c}-0.049 * * * \\
{[0.010]}\end{array}$ & $\begin{array}{c}-0.141^{* * *} \\
{[0.028]}\end{array}$ & $\begin{array}{c}-0.142 * * * \\
{[0.028]}\end{array}$ \\
\hline EBITDA/TA & $\begin{array}{c}0.803^{* * *} \\
{[0.054]}\end{array}$ & $\begin{array}{c}0.801^{* * *} \\
{[0.054]}\end{array}$ & $\begin{array}{c}1.515^{* * *} \\
{[0.124]}\end{array}$ & $\begin{array}{c}1.512 * * * \\
{[0.123]}\end{array}$ & $\begin{array}{c}0.803^{* * *} \\
{[0.054]}\end{array}$ & $\begin{array}{c}0.802 * * * \\
{[0.054]}\end{array}$ & $\begin{array}{c}1.515^{* * *} \\
{[0.123]}\end{array}$ & $\begin{array}{c}1.513 * * * \\
{[0.123]}\end{array}$ \\
\hline Leverage & $\begin{array}{c}-0.095 * * * \\
{[0.026]}\end{array}$ & $\begin{array}{c}-0.096^{* * *} \\
{[0.024]}\end{array}$ & $\begin{array}{c}-0.284^{* * *} \\
{[0.057]}\end{array}$ & $\begin{array}{c}-0.285^{* * *} \\
{[0.054]}\end{array}$ & $\begin{array}{c}-0.098 * * * \\
{[0.025]}\end{array}$ & $\begin{array}{c}-0.098 * * * \\
{[0.024]}\end{array}$ & $\begin{array}{c}-0.288^{* * *} \\
{[0.054]}\end{array}$ & $\begin{array}{c}-0.288 * * * \\
{[0.054]}\end{array}$ \\
\hline NPPE/TA & $\begin{array}{c}-0.119 * * * \\
{[0.025]}\end{array}$ & $\begin{array}{c}-0.112 * * * \\
{[0.025]}\end{array}$ & $\begin{array}{c}-0.115^{* *} \\
{[0.052]}\end{array}$ & $\begin{array}{l}-0.105^{*} \\
{[0.050]}\end{array}$ & $\begin{array}{c}-0.111^{* * *} \\
{[0.026]}\end{array}$ & $\begin{array}{c}-0.109 * * * \\
{[0.025]}\end{array}$ & $\begin{array}{l}-0.104^{*} \\
{[0.051]}\end{array}$ & $\begin{array}{c}-0.101^{*} \\
{[0.050]}\end{array}$ \\
\hline CAPEX/TA & $\begin{array}{c}0.490 * * * \\
{[0.164]}\end{array}$ & $\begin{array}{c}0.479 * * \\
{[0.166]}\end{array}$ & $\begin{array}{l}0.847^{* *} \\
{[0.349]}\end{array}$ & $\begin{array}{l}0.832 * * \\
{[0.351]}\end{array}$ & $\begin{array}{c}0.479 * * \\
{[0.168]}\end{array}$ & $\begin{array}{c}0.476^{* *} \\
{[0.168]}\end{array}$ & $\begin{array}{l}0.832^{* *} \\
{[0.355]}\end{array}$ & $\begin{array}{l}0.828^{* *} \\
{[0.354]}\end{array}$ \\
\hline $\mathrm{R} \& \mathrm{D} / \mathrm{TA}$ & $\begin{array}{c}0.350 \\
{[0.352]}\end{array}$ & $\begin{array}{c}0.354 \\
{[0.352]}\end{array}$ & $\begin{array}{c}0.995 \\
{[0.768]}\end{array}$ & $\begin{array}{c}1.001 \\
{[0.767]}\end{array}$ & $\begin{array}{c}0.348 \\
{[0.349]}\end{array}$ & $\begin{array}{c}0.350 \\
{[0.350]}\end{array}$ & $\begin{array}{c}0.992 \\
{[0.766]}\end{array}$ & $\begin{array}{c}0.996 \\
{[0.766]}\end{array}$ \\
\hline GDP growth & $\begin{array}{c}0.012 \\
{[0.007]}\end{array}$ & $\begin{array}{l}0.015^{* *} \\
{[0.006]}\end{array}$ & $\begin{array}{c}0.019 \\
{[0.014]}\end{array}$ & $\begin{array}{l}0.024^{*} \\
{[0.013]}\end{array}$ & $\begin{array}{c}0.010 \\
{[0.006]}\end{array}$ & $\begin{array}{l}0.012^{*} \\
{[0.006]}\end{array}$ & $\begin{array}{c}0.017 \\
{[0.012]}\end{array}$ & $\begin{array}{c}0.020 \\
{[0.013]}\end{array}$ \\
\hline $\log (G D P / c a p i t a)$ & $\begin{array}{c}0.013 \\
{[0.253]}\end{array}$ & $\begin{array}{l}-0.273 \\
{[0.206]}\end{array}$ & $\begin{array}{c}0.110 \\
{[0.401]}\end{array}$ & $\begin{array}{l}-0.293 \\
{[0.354]}\end{array}$ & $\begin{array}{l}-0.046 \\
{[0.157]}\end{array}$ & $\begin{array}{l}-0.184 \\
{[0.200]}\end{array}$ & $\begin{array}{c}0.021 \\
{[0.279]}\end{array}$ & $\begin{array}{l}-0.173 \\
{[0.354]}\end{array}$ \\
\hline $\begin{array}{l}\text { Relative change in domestic/USD- } \\
\text { exchange rate }\end{array}$ & $\begin{array}{l}-0.016 \\
{[0.077]}\end{array}$ & $\begin{array}{l}-0.027 \\
{[0.076]}\end{array}$ & $\begin{array}{l}-0.097 \\
{[0.118]}\end{array}$ & $\begin{array}{l}-0.111 \\
{[0.116]}\end{array}$ & $\begin{array}{c}-0.129 * \\
{[0.073]}\end{array}$ & $\begin{array}{l}-0.097 \\
{[0.077]}\end{array}$ & $\begin{array}{c}-0.256^{* *} \\
{[0.103]}\end{array}$ & $\begin{array}{c}-0.211^{*} \\
{[0.113]}\end{array}$ \\
\hline Short-term interest rate & & & & & $\begin{array}{c}-0.026^{* *} \\
{[0.009]}\end{array}$ & $\begin{array}{l}-0.016 \\
{[0.014]}\end{array}$ & $\begin{array}{c}-0.037 * * \\
{[0.015]}\end{array}$ & $\begin{array}{l}-0.023 \\
{[0.025]}\end{array}$ \\
\hline Term-spread & & & & & $\begin{array}{l}-0.014 \\
{[0.016]}\end{array}$ & $\begin{array}{l}-0.006 \\
{[0.018]}\end{array}$ & $\begin{array}{l}-0.021 \\
{[0.028]}\end{array}$ & $\begin{array}{l}-0.010 \\
{[0.033]}\end{array}$ \\
\hline Year dummies and fixed firm-effects & YES & YES & YES & YES & YES & YES & YES & YES \\
\hline $\mathrm{R}^{2}$ excluding fixed firm effects & 0.175 & 0.179 & 0.091 & 0.093 & 0.179 & 0.180 & 0.093 & 0.093 \\
\hline Number of firm-year observations & 36,246 & 36,246 & 36,246 & 36,246 & 36,246 & 36,246 & 36,246 & 36,246 \\
\hline $\begin{array}{l}\text { P-value from F-test: } \\
\text { Strong euro vs. weak euro firms }\end{array}$ & & $<0.000$ & & 0.000 & & 0.114 & & 0.229 \\
\hline
\end{tabular}


Panel B: Two-period (pre- and post euro) panel regressions

\begin{tabular}{|c|c|c|c|c|c|c|c|c|}
\hline \multirow[b]{2}{*}{ Explanatory variable: } & \multicolumn{2}{|c|}{$\begin{array}{c}\text { Dependent variable: } \\
\text { Log(Tobin’s Q) }\end{array}$} & \multicolumn{2}{|c|}{$\begin{array}{c}\text { Dependent variable: } \\
\text { Global industry-adjusted } \\
\text { Tobin’s Q }\end{array}$} & \multicolumn{2}{|c|}{$\begin{array}{c}\text { Dependent variable: } \\
\text { Log(Tobin's Q) }\end{array}$} & \multicolumn{2}{|c|}{$\begin{array}{c}\text { Dependent variable: } \\
\text { Global industry-adjusted } \\
\text { Tobin’s Q }\end{array}$} \\
\hline & $(1)$ & $(2)$ & $(3)$ & $(4)$ & $(5)$ & $(6)$ & $(7)$ & $(8)$ \\
\hline Euro country x post-euro dummy & $\begin{array}{l}0.110^{* *} \\
{[0.038]}\end{array}$ & & $\begin{array}{l}0.174^{* *} \\
{[0.068]}\end{array}$ & & $\begin{array}{l}0.095^{*} \\
{[0.045]}\end{array}$ & & $\begin{array}{l}0.153^{*} \\
{[0.087]}\end{array}$ & \\
\hline Strong euro country x post-euro dummy & & $\begin{array}{c}0.081 * * \\
{[0.031]}\end{array}$ & & $\begin{array}{l}0.140^{* *} \\
{[0.063]}\end{array}$ & & $\begin{array}{c}0.084 \\
{[0.050]}\end{array}$ & & $\begin{array}{c}0.154 \\
{[0.102]}\end{array}$ \\
\hline Weak euro country x post-euro dummy & & $\begin{array}{c}0.184^{* * *} \\
{[0.036]}\end{array}$ & & $\begin{array}{c}0.260 * * * \\
{[0.078]}\end{array}$ & & $\begin{array}{c}0.127 * * * \\
{[0.034]}\end{array}$ & & $\begin{array}{c}0.150 \\
{[0.103]}\end{array}$ \\
\hline Log (Sales) & $\begin{array}{c}-0.047 * * * \\
{[0.011]}\end{array}$ & $\begin{array}{c}-0.049 * * * \\
{[0.010]}\end{array}$ & $\begin{array}{c}-0.147 * * \\
{[0.051]}\end{array}$ & $\begin{array}{c}-0.149 * * * \\
{[0.050]}\end{array}$ & $\begin{array}{c}-0.049 * * * \\
{[0.011]}\end{array}$ & $\begin{array}{c}-0.049 * * * \\
{[0.011]}\end{array}$ & $\begin{array}{c}-0.149 * * \\
{[0.051]}\end{array}$ & $\begin{array}{c}-0.149 * * \\
{[0.052]}\end{array}$ \\
\hline EBITDA/TA & $\begin{array}{c}0.895^{* * *} \\
{[0.125]}\end{array}$ & $\begin{array}{c}0.890^{* * *} \\
{[0.121]}\end{array}$ & $\begin{array}{c}1.730 * * * \\
{[0.544]}\end{array}$ & $\begin{array}{c}1.723 * * * \\
{[0.538]}\end{array}$ & $\begin{array}{c}0.886 * * * \\
{[0.120]}\end{array}$ & $\begin{array}{c}0.887 * * * \\
{[0.119]}\end{array}$ & $\begin{array}{c}1.717 * * * \\
{[0.535]}\end{array}$ & $\begin{array}{c}1.717 * * * \\
{[0.536]}\end{array}$ \\
\hline Leverage & $\begin{array}{c}-0.072 * * \\
{[0.031]}\end{array}$ & $\begin{array}{c}-0.073 * * \\
{[0.028]}\end{array}$ & $\begin{array}{c}-0.162 * * \\
{[0.074]}\end{array}$ & $\begin{array}{c}-0.163 * * \\
{[0.071]}\end{array}$ & $\begin{array}{c}-0.080^{* *} \\
{[0.028]}\end{array}$ & $\begin{array}{c}-0.078 * * \\
{[0.027]}\end{array}$ & $\begin{array}{c}-0.174 * * \\
{[0.071]}\end{array}$ & $\begin{array}{c}-0.174^{* *} \\
{[0.071]}\end{array}$ \\
\hline NPPE/TA & $\begin{array}{c}-0.225^{* * *} \\
{[0.029]}\end{array}$ & $\begin{array}{c}-0.218^{* * *} \\
{[0.026]}\end{array}$ & $\begin{array}{c}-0.446 * * * \\
{[0.058]}\end{array}$ & $\begin{array}{c}-0.438 * * * \\
{[0.058]}\end{array}$ & $\begin{array}{c}-0.205^{* * *} \\
{[0.024]}\end{array}$ & $\begin{array}{c}-0.206 * * * \\
{[0.025]}\end{array}$ & $\begin{array}{c}-0.417 * * * \\
{[0.055]}\end{array}$ & $\begin{array}{c}-0.417 * * * \\
{[0.057]}\end{array}$ \\
\hline CAPEX/TA & $\begin{array}{c}0.083 \\
{[0.055]}\end{array}$ & $\begin{array}{c}0.081 \\
{[0.053]}\end{array}$ & $\begin{array}{c}0.155 \\
{[0.108]}\end{array}$ & $\begin{array}{c}0.152 \\
{[0.106]}\end{array}$ & $\begin{array}{c}0.078 \\
{[0.056]}\end{array}$ & $\begin{array}{c}0.078 \\
{[0.055]}\end{array}$ & $\begin{array}{c}0.148 \\
{[0.109]}\end{array}$ & $\begin{array}{c}0.148 \\
{[0.109]}\end{array}$ \\
\hline $\mathrm{R} \& \mathrm{D} / \mathrm{TA}$ & $\begin{array}{c}0.468 * * * \\
{[0.116]}\end{array}$ & $\begin{array}{c}0.469 * * * \\
{[0.111]}\end{array}$ & $\begin{array}{c}1.431^{* * *} \\
{[0.310]}\end{array}$ & $\begin{array}{c}1.433 * * * \\
{[0.305]}\end{array}$ & $\begin{array}{c}0.456^{* * *} \\
{[0.122]}\end{array}$ & $\begin{array}{c}0.455^{* * *} \\
{[0.121]}\end{array}$ & $\begin{array}{c}1.416^{* * *} \\
{[0.331]}\end{array}$ & $\begin{array}{c}1.416^{* * *} \\
{[0.332]}\end{array}$ \\
\hline GDP growth & $\begin{array}{l}0.182 * \\
{[0.089]}\end{array}$ & $\begin{array}{c}0.127 \\
{[0.091]}\end{array}$ & $\begin{array}{c}0.655^{* * *} \\
{[0.166]}\end{array}$ & $\begin{array}{c}0.591^{* * *} \\
{[0.169]}\end{array}$ & $\begin{array}{c}0.016 \\
{[0.063]}\end{array}$ & $\begin{array}{c}0.031 \\
{[0.075]}\end{array}$ & $\begin{array}{c}0.417^{* * *} \\
{[0.108]}\end{array}$ & $\begin{array}{c}0.416^{* * *} \\
{[0.131]}\end{array}$ \\
\hline $\log (G D P / c a p i t a)$ & $\begin{array}{l}0.031^{* *} \\
{[0.013]}\end{array}$ & $\begin{array}{c}0.038 * * * \\
{[0.011]}\end{array}$ & $\begin{array}{l}0.058^{* *} \\
{[0.024]}\end{array}$ & $\begin{array}{c}0.066^{* * *} \\
{[0.022]}\end{array}$ & $\begin{array}{l}0.024 * * \\
{[0.009]}\end{array}$ & $\begin{array}{l}0.028^{* *} \\
{[0.011]}\end{array}$ & $\begin{array}{l}0.048 * * \\
{[0.017]}\end{array}$ & $\begin{array}{c}0.048 * * \\
{[0.022]}\end{array}$ \\
\hline $\begin{array}{l}\text { Relative change in domestic/USD- } \\
\text { exchange rate }\end{array}$ & $\begin{array}{c}0.447^{* *} \\
{[0.206]}\end{array}$ & $\begin{array}{l}0.453^{* *} \\
{[0.184]}\end{array}$ & $\begin{array}{c}0.479 \\
{[0.363]}\end{array}$ & $\begin{array}{c}0.485 \\
{[0.335]}\end{array}$ & $\begin{array}{c}0.437 * * * \\
{[0.142]}\end{array}$ & $\begin{array}{c}0.477 * * * \\
{[0.159]}\end{array}$ & $\begin{array}{c}0.449 \\
{[0.295]}\end{array}$ & $\begin{array}{c}0.445 \\
{[0.322]}\end{array}$ \\
\hline Short-term interest rate & & & & & $\begin{array}{l}-0.031^{*} \\
{[0.016]}\end{array}$ & $\begin{array}{l}-0.020 \\
{[0.025]}\end{array}$ & $\begin{array}{l}-0.046 \\
{[0.031]}\end{array}$ & $\begin{array}{c}-0.047 \\
{[0.055]}\end{array}$ \\
\hline Term-spread & & & & & $\begin{array}{l}-0.005 \\
{[0.040]}\end{array}$ & $\begin{array}{c}0.003 \\
{[0.045]}\end{array}$ & $\begin{array}{l}-0.011 \\
{[0.075]}\end{array}$ & $\begin{array}{l}-0.012 \\
{[0.092]}\end{array}$ \\
\hline Post-euro time period dummy & $\begin{array}{c}-0.156^{* * *} \\
{[0.032]}\end{array}$ & $\begin{array}{c}-0.138 * * * \\
{[0.040]}\end{array}$ & $\begin{array}{c}-0.170^{* * *} \\
{[0.050]}\end{array}$ & $\begin{array}{c}-0.148 * * \\
{[0.057]}\end{array}$ & $\begin{array}{c}-0.141 \\
{[0.101]}\end{array}$ & $\begin{array}{l}-0.121 \\
{[0.113]}\end{array}$ & $\begin{array}{l}-0.155 \\
{[0.177]}\end{array}$ & $\begin{array}{l}-0.157 \\
{[0.213]}\end{array}$ \\
\hline Fixed firm-effects & YES & YES & YES & YES & YES & YES & YES & YES \\
\hline $\mathrm{R}^{2}$ excluding fixed firm effects & 0.285 & 0.292 & 0.144 & 0.146 & 0.295 & 0.295 & 0.148 & 0.148 \\
\hline Number of firm-year observations & 8,484 & 8,484 & 8,484 & 8,484 & 8,484 & 8,484 & 8,484 & 8,484 \\
\hline $\begin{array}{l}\text { P-value from F-test: } \\
\text { Strong euro vs. weak euro firms }\end{array}$ & & 0.001 & & 0.049 & & 0.371 & & 0.944 \\
\hline
\end{tabular}


Table 5. The introduction of the euro and corporate valuations: Robustness to Maastricht convergence criteria variables and changes in corporate taxation

The sample is an unbalanced panel of 4,242 firms from the Euro-countries (except Greece) and five Non-euro countries (Denmark, Norway, Sweden, Switzerland, and UK) with complete data in Worldscope over the time period 1994-2004. The dependent variable is the log of Tobin's Q. Estimation by OLS with fixed firm and year effects. All firm-level variables are winsorized at the $1^{\text {st }}$ and $99^{\text {th }}$ percentile value of the total sample. The post-euro time period is defined as the years 1998-2004. The euro-countries classified as weak (i.e., countries with a recent currency crisis) are: Finland, Italy, Ireland, Portugal and Spain. The four variables included to control for the formal convergence criteria of the Maastricht treaty are: government budget deficit, government debt/GDP, the annual inflation rate, and the nominal long-term (10 year) interest rate. In column (1), the convergence variables are calculated as the deviations from the Maastricht criteria for each criterion that is not fulfilled, and are set to zero otherwise. In column (2) the convergence variables are included without any adjustments. The corporate tax-rate is the domestic corporate tax-rate faced by public firms as reported by KPMG. The same set of firm and country control variables as in Table 4 (expect short-term interest rate and the term spread) are included but not reported. Standard errors robust to clustering on country level are reported within brackets. *, **, and ***, indicates significance at the $10 \%, 5 \%$, and $1 \%$-levels, respectively.

\begin{tabular}{lcc}
\hline & \multicolumn{2}{c}{ Dependent variable: Log(Tobin's Q) } \\
\cline { 2 - 3 } Explanatory variable: & $\begin{array}{c}\text { Adjusted convergence } \\
\text { variables }\end{array}$ & $\begin{array}{c}\text { Unadjusted convergence } \\
\text { variables }\end{array}$ \\
\cline { 2 - 3 } Strong euro country x post-euro dummy & $(1)$ & $(2)$ \\
\cline { 2 - 3 } Weak euro country x post-euro dummy & $0.061^{* *}$ & $0.075^{*}$ \\
& {$[0.027]$} & $0.037]$ \\
Convergence criteria variables: & $0.152^{* * *}$ & {$[0.029]$} \\
\multicolumn{1}{c}{ Government deficit } & {$[0.026]$} & 0.329 \\
& & {$[0.381]$} \\
Government debt/GDP & -0.419 & 0.088 \\
Inflation rate & {$[0.972]$} & {$[0.078]$} \\
Long-term nominal interest rate & -0.053 & 0.087 \\
Corporate tax rate & {$[0.126]$} & {$[0.596]$} \\
Firm and country controls & -0.249 & -0.017 \\
Year dummies and fixed firm-effects & {$[1.374]$} & {$[0.010]$} \\
R $^{2}$ excluding fixed firm effects & $-0.041^{* *}$ & 0.124 \\
Number of observations & {$[0.017]$} & {$[0.115]$} \\
\hline P-value from F-test: & $0.204^{*}$ & YES \\
Strong euro country vs. weak euro country & {$[0.114]$} & YES \\
\hline
\end{tabular}


Table 6. The introduction of the euro and corporate valuations: The impact of euro exchange rate exposure

The sample is an unbalanced panel of 3,017 firms from the Euro-countries (except Greece) and five Non-euro countries (Denmark, Norway, Sweden, Switzerland, and UK) with available data in Worldscope over the time period 1994-2004. The dependent variable is the log of Tobin's Q. Estimation by OLS with fixed firm and year effects. All firm-level variables are winsorized at the $1^{\text {st }}$ and $99^{\text {th }}$ percentile value of the total sample. The post-euro time period is defined as the years 1998-2004. The euro-countries classified as weak (i.e., countries with a recent currency crisis) are: Finland, Italy, Ireland, Portugal and Spain. The euro exchange rate exposure is measured as the exchange rate beta from a two-factor model of stock returns in which changes in the (synthetic) euro exchange rate and the domestic stock market return are the two factors. The estimations of exchange rate betas (ERBs) are performed using monthly data over the time period January 1992 to December 1994. A significant positive (negative) ERB implies that the firm benefits (is hurt) when the firm's domestic currency depreciates relative to the synthetic euro. A firm is classified as having a significant (positive or negative) ERB if it is significant at the 5\%level according to a one-sided t-test. The same set of firm and country control variables as in Table 4 are included but not reported. Standard errors robust to clustering on country level are reported within brackets. *, **, and ***, indicates significance at the $10 \%, 5 \%$, and $1 \%$-levels, respectively.

\begin{tabular}{|c|c|c|}
\hline \multirow[b]{2}{*}{ Explanatory variable: } & \multicolumn{2}{|c|}{ Dependent variable: Log(Tobin’s Q) } \\
\hline & $(1)$ & $(2)$ \\
\hline Strong euro country x post-euro dummy & $\begin{array}{c}0.064 * \\
{[0.032]}\end{array}$ & $\begin{array}{c}0.065^{*} \\
{[0.037]}\end{array}$ \\
\hline Strong euro country $\mathrm{x}$ sign. positive ERB x post-euro dummy & $\begin{array}{c}-0.015 \\
{[0.014]}\end{array}$ & $\begin{array}{l}-0.014 \\
{[0.014]}\end{array}$ \\
\hline Strong euro country x sign. negative ERB x post-euro dummy & $\begin{array}{c}-0.023 \\
{[0.027]}\end{array}$ & $\begin{array}{c}-0.023 \\
{[0.027]}\end{array}$ \\
\hline Weak euro country x post-euro dummy & $\begin{array}{c}0.156^{* * *} \\
{[0.025]}\end{array}$ & $\begin{array}{c}0.108 * * * \\
{[0.031]}\end{array}$ \\
\hline Weak euro country x sign. positive ERB x post-euro dummy & $\begin{array}{c}0.036 \\
{[0.056]}\end{array}$ & $\begin{array}{c}0.036 \\
{[0.055]}\end{array}$ \\
\hline Weak euro country x sign. negative ERB x post-euro dummy & $\begin{array}{c}0.068 * * * \\
{[0.018]}\end{array}$ & $\begin{array}{c}0.064 * * * \\
{[0.018]}\end{array}$ \\
\hline Firm and country controls & YES & YES \\
\hline Short-term interest rate and term spread & NO & YES \\
\hline Year dummies and fixed firm-effects & YES & YES \\
\hline $\mathrm{R}^{2}$ excluding fixed firm effects & 0.147 & 0.149 \\
\hline Number of firm-year observations & 27,349 & 27,349 \\
\hline \multicolumn{3}{|l|}{ P-value from F-test: } \\
\hline Strong euro $\mathrm{x}$ sign. positive ERB vs. strong euro $\mathrm{x}$ sign. negative ERB & 0.820 & 0.807 \\
\hline Weak euro $x$ sign. positive ERB vs. weak euro $x$ sign. negative ERB & 0.603 & 0.629 \\
\hline Strong euro $\mathrm{x}$ sign. positive ERB vs. weak euro $\mathrm{x}$ sign. positive ERB & 0.400 & 0.399 \\
\hline Strong euro x sign. negative ERB vs. weak euro $\mathrm{x}$ sign. negative ERB & 0.010 & 0.013 \\
\hline
\end{tabular}


Table 7. The introduction of the euro and corporate valuations: Large vs. small firms

The sample is an unbalanced panel of 4,242 firms from the Euro-countries (except Greece) and five Non-euro countries (Denmark, Norway, Sweden, Switzerland, and UK) with complete data in Worldscope over the time period 1994-2004. The dependent variable is the log of Tobin's Q. Estimation by OLS with fixed firm and year effects. All firm-level variables are winsorized at the $1^{\text {st }}$ and $99^{\text {th }}$ percentile value of the total sample. The post-euro time period is defined as the years 1998-2004. The euro-countries classified as weak (i.e., countries with a recent currency crisis) are: Finland, Italy, Ireland, Portugal and Spain. A firm is classified as large if its sales are above the median sales of the sample in 1997; otherwise it is classified as small. The same set of firm and country control variables as in Table 4 are included but not reported. Standard errors robust to clustering on country level are reported within brackets. $*$, **, and ***, indicates significance at the $10 \%, 5 \%$, and 1\%-levels, respectively.

\begin{tabular}{lcc}
\hline & Dependent variable: Log(Tobin's Q) \\
\cline { 2 - 3 } Explanatory variable: & $(1)$ & $(2)$ \\
\hline Strong euro country x large firm x post-euro dummy & 0.057 & 0.061 \\
Strong euro country x small firm x post-euro dummy & {$[0.039]$} & {$[0.044]$} \\
& $0.055^{* * *}$ & $0.059^{* *}$ \\
Weak euro country x large firm x post-euro dummy & {$[0.017]$} & {$[0.023]$} \\
& $0.155^{* * *}$ & $0.111^{* *}$ \\
Weak euro country x small firm x post-euro dummy & {$[0.033]$} & {$[0.038]$} \\
& $0.194^{* * *}$ & $0.153^{* * *}$ \\
Large firm x post-euro dummy & {$[0.036]$} & $0.039]$ \\
& 0.012 & 0.012 \\
Firm and country controls & {$[0.024]$} & YES \\
Short-term interest rate and term spread & YES & YES \\
Year dummies and fixed firm-effects & NO & YES \\
$R^{2}$ excluding fixed firm effects & YES & 0.180 \\
Number of observations & 0.179 & 36,246 \\
\hline P-value from F-test: & 36,246 & \\
Strong euro x large firm vs. strong euro x small firm & & 0.944 \\
Weak euro x large firm vs. weak euro x small firm & 0.967 & 0.312 \\
Strong euro x large firm vs. weak euro x large firm & 0.381 & 0.235 \\
Strong euro x small firm vs. weak euro x small firm & 0.001 & 0.077 \\
\hline
\end{tabular}


Table 8. The introduction of the euro and corporate valuations: Effects by individual euro countries

The sample is an unbalanced panel of 4,242 firms from the Euro-countries (except Greece) and five Non-euro countries (Denmark, Norway, Sweden, Switzerland, and UK) with complete data in Worldscope over the time period 1994-2004. The dependent variable is the log of Tobin's Q. Estimation by OLS with fixed firm and year effects. All firm-level variables are winsorized at the $1^{\text {st }}$ and $99^{\text {th }}$ percentile value of the total sample. The post-euro time period is defined as the years 1998-2004. The euro-countries classified as weak (i.e., countries with a recent currency crisis) are: Finland, Italy, Ireland, Portugal and Spain. The same set of firm and country control variables as in Table 4 are included but not reported. Standard errors robust to clustering on country level are reported within brackets. ${ }^{*}, * *$, and $* * *$, indicates significance at the $10 \%, 5 \%$, and $1 \%$-levels, respectively.

\begin{tabular}{|c|c|c|}
\hline \multirow[b]{2}{*}{ Explanatory variable: } & \multicolumn{2}{|c|}{ Dependent variable: Log(Tobin’s Q) } \\
\hline & $(1)$ & (2) \\
\hline \multicolumn{3}{|l|}{ Strong euro countries } \\
\hline \multirow[t]{2}{*}{ Austria x post-euro dummy } & 0.017 & 0.021 \\
\hline & {$[0.025]$} & {$[0.032]$} \\
\hline \multirow[t]{2}{*}{ Belgium x post-euro dummy } & $0.064^{* * *}$ & $0.064 * *$ \\
\hline & [0.019] & {$[0.024]$} \\
\hline \multirow[t]{2}{*}{ France x post-euro dummy } & $0.088^{* * *}$ & $0.086 * *$ \\
\hline & {$[0.028]$} & {$[0.037]$} \\
\hline \multirow[t]{2}{*}{ Germany x post-euro dummy } & 0.046 & 0.052 \\
\hline & {$[0.030]$} & {$[0.035]$} \\
\hline \multirow{2}{*}{ Luxemburg x post-euro dummy } & $-0.083^{*}$ & -0.091 \\
\hline & [0.043] & {$[0.052]$} \\
\hline \multirow[t]{2}{*}{ Netherlands x post-euro dummy } & $0.047 * *$ & $0.050^{*}$ \\
\hline & {$[0.021]$} & {$[0.027]$} \\
\hline \multicolumn{3}{|l|}{ Weak euro countries } \\
\hline \multirow[t]{2}{*}{ Finland x post-euro dummy } & $0.132 * * *$ & $0.119 * * *$ \\
\hline & [0.039] & {$[0.036]$} \\
\hline \multirow{2}{*}{ Ireland x post-euro dummy } & 0.112 & 0.082 \\
\hline & {$[0.110]$} & {$[0.095]$} \\
\hline \multirow[t]{2}{*}{ Italy x post-euro dummy } & $0.195 * * *$ & $0.146 * * *$ \\
\hline & {$[0.026]$} & {$[0.029]$} \\
\hline \multirow[t]{2}{*}{ Portugal post-euro dummy } & $0.170^{* * *}$ & $0.124^{* * *}$ \\
\hline & {$[0.022]$} & [0.033] \\
\hline \multirow[t]{2}{*}{ Spain $\mathrm{x}$ post-euro dummy } & $0.170^{* * *}$ & $0.132 * * *$ \\
\hline & {$[0.029]$} & {$[0.035]$} \\
\hline Short-term interest rate and term spread & NO & YES \\
\hline Firm and country controls & YES & YES \\
\hline Year dummies and fixed firm-effects & YES & YES \\
\hline $\mathrm{R}^{2}$ excluding fixed firm effects & 0.180 & 0.181 \\
\hline Number of firm-year observations & 36,246 & 36,246 \\
\hline
\end{tabular}


Table 9. The introduction of the euro and corporate valuations: Change in cost of equity?

The sample is an unbalanced panel of 3,756 firms from the Euro-countries (except Greece) and five Non-euro countries (Denmark, Norway, Sweden, Switzerland, and UK) with data in Worldscope over the time period 19942004. The dependent variable is the cost of equity in columns (1) and (2), and is the log of Tobin's Q in columns (3) and (4). Estimation by OLS with fixed firm and year effects. Cost of equity is estimated as the consensus forecast of earnings per share divided by the stock price. The forecast data is from I/B/E/S. All firm-level variables are winsorized at the $1^{\text {st }}$ and $99^{\text {th }}$ percentile value of the total sample. The post-euro time period is defined as the years 1998-2004. The euro-countries classified as weak (i.e., countries with a recent currency crisis) are: Finland, Italy, Ireland, Portugal and Spain. The same set of firm and country control variables as in Table 4 are included but not reported. Standard errors robust to clustering on country level are reported within brackets. *, **, and ***, indicates significance at the $10 \%, 5 \%$, and $1 \%$-levels, respectively.

\begin{tabular}{|c|c|c|c|c|}
\hline \multirow[b]{2}{*}{ Explanatory variable: } & \multicolumn{2}{|c|}{$\begin{array}{l}\text { Dependent variable: } \\
\text { Cost of equity }\end{array}$} & \multicolumn{2}{|c|}{$\begin{array}{l}\text { Dependent variable: } \\
\text { Log(Tobin’s Q) }\end{array}$} \\
\hline & $(1)$ & $(2)$ & (3) & $(4)$ \\
\hline Strong euro country x post-euro dummy & $\begin{array}{c}0.003 \\
{[0.006]}\end{array}$ & $\begin{array}{c}0.006 \\
{[0.005]}\end{array}$ & $\begin{array}{c}0.058 * * \\
{[0.026]}\end{array}$ & $\begin{array}{c}0.057^{*} \\
{[0.032]}\end{array}$ \\
\hline Weak euro country x post-euro dummy & $\begin{array}{c}-0.025 * * * \\
{[0.005]}\end{array}$ & $\begin{array}{c}-0.009 \\
{[0.009]}\end{array}$ & $\begin{array}{c}0.145^{* * *} \\
{[0.020]}\end{array}$ & $\begin{array}{c}0.115^{* * *} \\
{[0.031]}\end{array}$ \\
\hline Cost of equity & & & $\begin{array}{c}-0.932 * * * \\
{[0.139]}\end{array}$ & $\begin{array}{c}-0.921^{* * *} \\
{[0.140]}\end{array}$ \\
\hline Firm and country controls & YES & YES & YES & YES \\
\hline Short-term interest rate and term spread & NO & YES & NO & YES \\
\hline Year dummies and fixed firm-effects & YES & YES & YES & YES \\
\hline $\mathrm{R}^{2}$ excluding fixed firm effects & 0.048 & 0.055 & 0.245 & 0.247 \\
\hline Number of observations & 27,691 & 27,691 & 27,691 & 27,691 \\
\hline $\begin{array}{l}\text { P-value from F-test: } \\
\text { Strong euro vs. weak euro firms }\end{array}$ & 0.003 & 0.006 & 0.058 & 0.057 \\
\hline
\end{tabular}




\section{Table 10. The introduction of the euro and stock returns}

We construct within-country portfolios of monthly stock returns, classified by the ERB of the firms in the country. Within each country, we construct three value-weighted portfolios: one portfolio contains all firms whose ERB is positive and significant. A second portfolio contains all firms whose ERB is negative and significant. The third portfolio contains all other firms, for which the currency exposure is not significant. Stock returns and market capitalization is from Datastream. We therefore have 132 monthly observations on $16 \times 3$ portfolios (a total of 6,336 observations). The event window is from November 1997 through May 1998. We then regress monthly returns on the MSCI World Index, the MSCI Europe index, and event dummies, interacted with portfolio characteristics (ERBs) and country characteristics (euro membership and strong/weak classification). The euro-countries classified as weak (i.e., countries with a recent currency crisis) are: Finland, Italy, Ireland, Portugal and Spain. Standard errors robust to heteroskedasticity are reported within brackets. *, **, and $* * *$, indicates significance at the $10 \%, 5 \%$, and $1 \%$-levels, respectively.

Dependent Variable: Monthly Returns on Value-

Explanatory variable: Weighted, Within Country Portfolios

\begin{tabular}{|c|c|c|c|c|}
\hline Explanatory variable: & (1) & (2) & (3) & (4) \\
\hline Constant & $\begin{array}{c}0.010^{* * *} \\
{[0.001]}\end{array}$ & $\begin{array}{c}0.010 * * * \\
{[0.001]}\end{array}$ & $\begin{array}{c}0.012 * * * \\
{[0.001]}\end{array}$ & $\begin{array}{c}0.012^{* * *} \\
{[0.001]}\end{array}$ \\
\hline MSCI World & $\begin{array}{c}0.543 * * * \\
{[0.028]}\end{array}$ & $\begin{array}{c}0.543 * * * \\
{[0.028]}\end{array}$ & $\begin{array}{c}0.543 * * * \\
{[0.028]}\end{array}$ & $\begin{array}{c}0.543 * * * \\
{[0.028]}\end{array}$ \\
\hline MSCI Europe & $\begin{array}{c}0.061^{* * *} \\
{[0.020]}\end{array}$ & $\begin{array}{c}0.062 * * * \\
{[0.020]}\end{array}$ & $\begin{array}{c}0.062 * * * \\
{[0.020]}\end{array}$ & $\begin{array}{c}0.062 * * * \\
{[0.020]}\end{array}$ \\
\hline EMU Country x Intro Euro & $\begin{array}{c}0.034^{* * *} \\
{[0.008]}\end{array}$ & $\begin{array}{c}0.004 \\
{[0.007]}\end{array}$ & $\begin{array}{l}0.020^{*} \\
{[0.000]}\end{array}$ & $\begin{array}{c}0.047 * * * \\
{[0.011]}\end{array}$ \\
\hline Weak EMU Country x Intro Euro & & $\begin{array}{c}0.053^{* * *} \\
{[0.015]}\end{array}$ & $\begin{array}{c}0.056 * * * \\
{[0.014]}\end{array}$ & \\
\hline ERB Positive and Significant & & & $\begin{array}{c}-0.002 \\
{[0.002]}\end{array}$ & $\begin{array}{c}0 \\
{[0.003]}\end{array}$ \\
\hline ERB Positive and Significant $x$ Intro Euro & & & $\begin{array}{c}-0.031 \\
{[0.020]}\end{array}$ & $\begin{array}{c}-0.053 * * * \\
{[0.014]}\end{array}$ \\
\hline ERB Negative and Significant & & & $\begin{array}{c}-0.002 \\
{[0.002]}\end{array}$ & $\begin{array}{c}0.001 \\
{[0.002]}\end{array}$ \\
\hline ERB Negative and Significant x Intro Euro & & & $\begin{array}{c}-0.021 \\
{[0.015]}\end{array}$ & $\begin{array}{c}-0.060 * * * \\
{[0.012]}\end{array}$ \\
\hline ERB Negative and Significant x Weak EMU & & & & $\begin{array}{l}-0.008^{*} \\
{[0.004]}\end{array}$ \\
\hline ERB Negative and Significant $x$ Intro Euro x Weak EMU & & & & $\begin{array}{c}0.078 * * * \\
{[0.021]}\end{array}$ \\
\hline ERB Positive and Significant $x$ Weak EMU & & & & $\begin{array}{c}-0.006 \\
{[0.005]}\end{array}$ \\
\hline ERB Positive and Significant x Intro Euro x Weak EMU & & & & $\begin{array}{c}0.046 \\
{[0.031]}\end{array}$ \\
\hline Year dummies and country-fixed effects & YES & YES & YES & YES \\
\hline $\mathrm{R}^{2}$ excluding fixed firm effects & 0.09 & 0.09 & 0.09 & 0.09 \\
\hline Number of firm-year observations & 6,336 & 6,336 & 6,336 & 6,336 \\
\hline$P$-value from F-test: & & & & \\
\hline ERB Positive vs. ERB Negative & & & 0.8869 & 0.6532 \\
\hline ERB Positive $x$ Euro vs. ERB Negative x Euro & & & 0.4321 & 0.1741 \\
\hline $\begin{array}{l}\text { Weak EMU x ERB Positive vs. Weak EMU x ERB } \\
\text { Negative }\end{array}$ & & & & 0.6547 \\
\hline $\begin{array}{l}\text { Weak EMU x ERB Positive x Euro vs. Weak EMU x } \\
\text { ERB Negative x Euro }\end{array}$ & & & & 0.0012 \\
\hline
\end{tabular}




\section{Table 11. Swedish EMU Referendum Poll Results and Individual Firm Stock Returns}

We regress individual firm weekly stock returns for firms in Sweden on the domestic market return, the change in exchange rate between the euro and the dollar, and indicators of poll results related to the Swedish referendum in September 14, 2003. The polls are conducted in the months prior to the referendum. We calculate two dummy variables: the first dummy equals one if the percent of "Yes" votes in an opinion poll increases relative to the previous one, zero otherwise. The second dummy variable equals one if the percent of "Yes" votes in the poll exceeds the percent of "No" votes in the poll. We ignore undecided voters. The poll data for Sweden has been collected by Synovate Temo, and can be found in http://www.temo.se/dok/proj/EMU/EMUsamtliga.asp. Stock prices and exchange rates are from Datastream. . The euro exchange rate exposure is measured as the exchange rate beta from a two-factor model of stock returns in which changes in the (synthetic) euro exchange rate and the domestic stock market return are the two factors. The estimations of exchange rate betas (ERBs) are performed using monthly data over the time period January 1992 to December 1994. A significant positive (negative) ERB implies that the firm benefits (is hurt) when the firm's domestic currency depreciates relative to the synthetic euro. A firm is classified as having a significant (positive or negative) ERB if it is significant at the 5\%-level according to a one-sided t-test. Standard errors robust to heteroskedasticity are reported within brackets. *, **, and ***, indicates significance at the $10 \%, 5 \%$, and $1 \%$-levels, respectively.

\begin{tabular}{|c|c|c|}
\hline & \multicolumn{2}{|c|}{$\begin{array}{c}\text { Dependent Variable: Individual Firm Weekly } \\
\text { Returns }\end{array}$} \\
\hline & $(1)$ & $(2)$ \\
\hline Increase in "Yes" relative to previous week & $\begin{array}{c}0.021 * \\
{[0.012]}\end{array}$ & \\
\hline Increase in "Yes" x ERB negative and Significant & $\begin{array}{c}0.034 \\
{[0.021]}\end{array}$ & \\
\hline Increase in "Yes" x ERB positive and Significant & $\begin{array}{c}-0.077 * * * \\
{[0.030]}\end{array}$ & \\
\hline "Yes"> "No" & & $\begin{array}{c}-0.002 \\
{[0.004]}\end{array}$ \\
\hline "Yes"> "No" x ERB negative and Significant & & $\begin{array}{c}0.008 * \\
{[0.005]}\end{array}$ \\
\hline "Yes"> "No" x ERB positive and Significant & & $\begin{array}{c}-0.017^{* *} \\
{[0.007]}\end{array}$ \\
\hline Market Return & $\begin{array}{c}0.647^{* * * *} \\
{[0.086]}\end{array}$ & $\begin{array}{c}0.584 * * * \\
{[0.078]}\end{array}$ \\
\hline Change in Exchange Rate Euro / Dollar & $\begin{array}{c}-0.183 * * \\
{[0.088]}\end{array}$ & $\begin{array}{c}-0.199 * * \\
{[0.089]}\end{array}$ \\
\hline Constant & $\begin{array}{c}0.010^{* * *} \\
{[0.003]}\end{array}$ & $\begin{array}{c}0.010 * * * \\
{[0.004]}\end{array}$ \\
\hline Number of Firm - Week Observations & 2,964 & 2,964 \\
\hline R-squared & 0.02 & 0.02 \\
\hline
\end{tabular}




\section{Table B.1 Euro exchange rate exposure}

The euro exchange rate exposure is measured as the exchange rate beta from a two-factor model of stock returns in which changes in the (synthetic) euro exchange rate and the domestic stock market return are the two factors. The estimations of exchange rate betas are performed using monthly data over the time period January 1992 to December 1994. All data is from DataStream. The \% Significant is based on significance at the 5\%-level.

\begin{tabular}{|c|c|c|c|c|c|c|}
\hline \multirow[b]{2}{*}{ Country } & \multirow[b]{2}{*}{$\mathrm{N}$} & \multirow{2}{*}{$\begin{array}{c}\text { Median } \\
\text { Exchange } \\
\text { Rate Beta }\end{array}$} & \multicolumn{2}{|c|}{ Positive Exchange Rate Beta } & \multicolumn{2}{|c|}{ Negative Exchange Rate Beta } \\
\hline & & & $\mathrm{N}$ & \% Significant & \% Firms & \% Significant \\
\hline \multicolumn{7}{|c|}{ Euro countries: } \\
\hline Austria & 56 & -0.306 & 19 & 21.1 & 37 & 18.9 \\
\hline Belgium & 80 & -0.027 & 36 & 11.1 & 44 & 13.6 \\
\hline Finland & 43 & -0.213 & 15 & 40.0 & 28 & 32.1 \\
\hline France & 394 & 0.124 & 212 & 17.5 & 182 & 17.6 \\
\hline Germany & 444 & 0.074 & 238 & 18.9 & 206 & 13.6 \\
\hline Ireland & 36 & -0.779 & 8 & 37.5 & 28 & 35.7 \\
\hline Italy & 130 & -0.341 & 42 & 23.8 & 88 & 36.4 \\
\hline Luxemburg & 0 & $\mathrm{n} / \mathrm{a}$ & $\mathrm{n} / \mathrm{a}$ & $\mathrm{n} / \mathrm{a}$ & $\mathrm{n} / \mathrm{a}$ & $\mathrm{n} / \mathrm{a}$ \\
\hline Netherlands & 133 & 0.764 & 102 & 29.4 & 31 & 9.7 \\
\hline Portugal & 59 & 0.425 & 39 & 28.2 & 20 & 10.0 \\
\hline Spain & 103 & -0.244 & 43 & 32.6 & 60 & 26.7 \\
\hline Total & 1,534 & 0.021 & 780 & 21.2 & 754 & 22.0 \\
\hline \multicolumn{7}{|c|}{ Non-euro countries: } \\
\hline Denmark & 161 & -0.046 & 81 & 28.4 & 80 & 10.0 \\
\hline Norway & 75 & 0.034 & 31 & 19.4 & 44 & 25.0 \\
\hline Sweden & 107 & -0.481 & 43 & 27.9 & 64 & 46.9 \\
\hline Switzerland & 120 & 0.068 & 65 & 16.9 & 55 & 20.0 \\
\hline UK & 1,076 & -0.497 & 297 & 16.4 & 779 & 35.3 \\
\hline Total & 1,539 & -0.321 & 517 & 19.5 & 1,022 & 32.8 \\
\hline
\end{tabular}


Figure 1. Forward Rate Differentials as measures of the Probability of Convergence to the EMU.

The figure shows forward rate differentials with Germany, averaged across areas within Europe. We estimate market-based probabilities of adopting the euro for the fifteen countries in our sample from forward rates differentials. We calculate monthly forward rate differentials from swap rates between fixed and floating rate government bonds. We calculate 8-year forward rates in 2 years, and then calculate spreads for each country with respect to Germany, as $s_{\mathrm{it}}=\ln \left(1+\mathrm{f}_{\mathrm{i}, 2, \mathrm{t}}^{\mathrm{B}}\right)^{-}$ $\ln \left(1+f_{\mathrm{GE}, 2 \mathrm{t}}^{8}\right)$, where $\mathrm{sit}_{\mathrm{it}}$ is the forward rate spread for country $\mathrm{i}$ in month $\mathrm{t}$, and $\mathrm{f}_{\mathrm{i}, 2, \mathrm{t}}^{8}$ and $\mathrm{f}_{\mathrm{GE}, 2, \mathrm{t}}^{8}$ are respectively the 8-year forward rates in 2 years for country i and Germany. We use the spread between the German forward rate and the ECU forward rate as a measure of the German spread. Swap data is from Datastream. As in Hardouvelis (2001), we adjust for market conventions on national swap markets. In all countries in the sample coupons are paid annually, except for Ireland and the UK, where they are paid semiannually. We annualize interest rates in both countries. We additionally convert swap yields to a 360 days in Belgium, Ireland, and the UK, where the convention is 365 day-years.

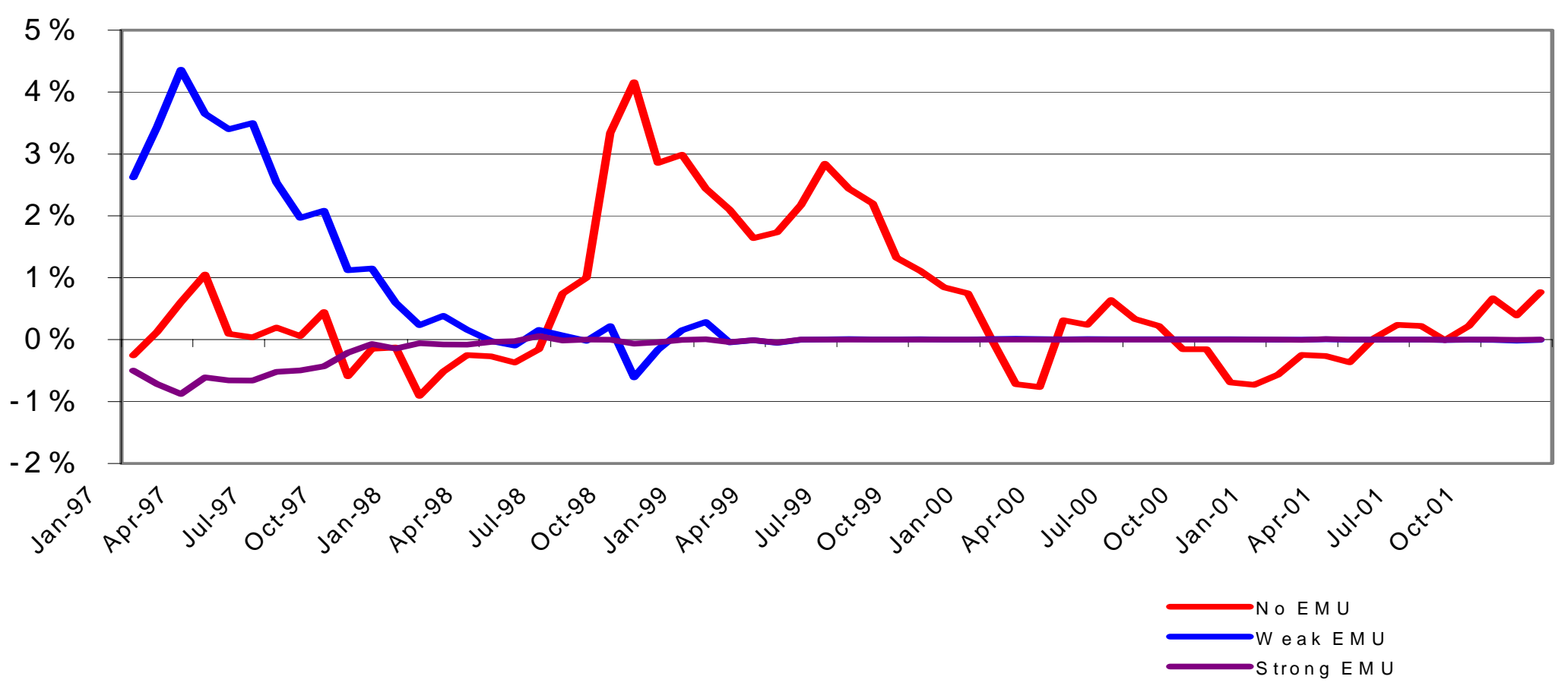

